\title{
Anorogenic Early Permian dykes in the western Mongolian Altai - petrography, geochemistry and K-Ar geochronology
}

\author{
Vladimír ŽÁČEK ${ }^{*}$, David BURIÁNEK ${ }^{1}$,Zoltán PÉCSKAY², Radek ŠKODA ${ }^{1}$ \\ ${ }^{1}$ Czech Geological Survey, Klárov 3, 11821 Prague 1, Czech Republic; vladimir.zacek@geology.cz \\ ${ }^{2}$ Isotope Climatology and Environmental Research Centre (ICER), Institute for Nuclear Research (ATOMKI), Hungarian Academy of \\ Sciences, 4026 Bem tér 18/c, Debrecen, Hungary \\ * Corresponding author
}

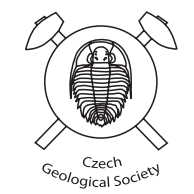

A variety of felsic and mafic dykes grouped into swarms intruded the Lower Palaeozoic volcano-sedimentary sequences (flysch) and Late Devonian to Early Carboniferous plutonic rocks in the Hovd and Altai zones of the Central Asian Orogenic Belt (CAOB), western Mongolian Altai. The dykes reach a thickness of 0.5-20 m, length of approximately 50-2,500 $\mathrm{m}$ and strike mostly SW-NE or E-W. The felsic rocks chemically correspond to high-K calc-alkaline to alkaline rhyolites. Compositional trends of mafic rocks pass from alkaline- and calc-alkaline basalts to trachyandesite. The bimodal nature of the association and the transitional calc-alkaline to alkaline character of the dykes indicate magma production through partial melting of the mantle and continental crust in an intra-plate (rift) geodynamic setting.

The new conventional whole-rock $\mathrm{K}$-Ar dating of mafic and felsic dykes yielded ages ranging from $300 \pm 9$ to $281 \pm 9 \mathrm{Ma}$ $(1 \sigma)$. This indicates anorogenic volcanic activity associated with Late Carboniferous to Early Permian extension coeval with magmatism in the Gobi-Altai Rift and in the adjacent parts of the Chinese Altai. The calculated crystallization pressures of 1-2 kbar and 0.3-0.4 kbar for felsic and mafic rocks, respectively, indicate emplacement at shallow levels.

Keywords: dyke, Permian, K-Ar geochronology, Altai, CAOB

Received: 1 January 2019; accepted: 5 April 2019; handling editor: P. Hasalová

The online version of this article (doi: 10.3190/jgeosci.280) contains supplementary electronic material.

\section{Introduction}

Late Palaeozoic rift-related intrusive and extrusive igneous rocks are relatively common in northern China and Mongolia (Gavrilova et al. 1975; Wang ZG et al. 1993; Litvinovsky et al. 2002; Wu et al. 2002; Chen and Jahn 2004; Jahn 2004; Chen and Arakawa 2005; Wang Q et al. 2007; Buriánek et al. 2012; Liu W et al. 2013; Mao et al. 2014). These undeformed anorogenic-type intrusions provide evidence of the final amalgamation of terranes in this part of the CAOB (Jahn 2004; Liu W et al. 2013; Mao et al. 2014). Yarmolyuk and Kovalenko VI (1991, 2001) assumed the existence of five linear systems controlled by large $\mathrm{E}-\mathrm{W}$ oriented faults and related to Late Palaeozoic igneous bimodal associations. These zones represent parts of the Asian rift system and from south to north are as follows: Gobi-Tien Shan, Main Mongolian Lineament, Gobi-Altai, North Gobi and North Mongolian-Trans-Baikalian, respectively (Kovalenko DV and Chernov 2008).

According to e.g. Jahn et al. (2009) or Yarmolyuk et al. (2013a), there is a western termination of the Northern Mongolian-Trans-Baikalian Rift situated at the boundary of Hovd and Lake zones. This paper is aimed at providing new petrological, geochemical and $\mathrm{K}-\mathrm{Ar}$ geochronological data on the variety of mafic and felsic anorogenic dykes of the Late Carboniferous to Early Permian age, occurring in this key region of the western Mongolian Altai.

\section{Geological setting}

The study area (Fig. 1) is situated in the Hovd and Altai zones/terranes of the CAOB, which represents the largest accretionary system on Earth $(\sim 8,000 \times 6,000 \mathrm{~km})$ formed as a result of the subduction and closure of the Paleo-Asian Ocean (e.g. Zonenshain et al. 1990; Şengör et al. 1993; Jahn et al. 2000; Buslov et al. 2001; Liu Q et al. 2017). The CAOB is a complex mosaic of continental blocks, accretionary wedges, magmatic arcs, back-arcs and fragments of oceanic crust amalgamated during the Palaeozoic to Mesozoic times (Şengör et al. 1993).

The Hovd and Altai zones are interpreted as parts of the accretionary wedge and fore-arc basin, respectively (Badarch et al. 2002; Xiao et al. 2004). Both zones are composed of several lithostratigraphic units of documented or supposed Ordovician to Early Devonian ages (Žáček et al. 2017a, b). Existing geochronological studies from the Chinese Altai suggest that similar rocks were deposited during the Ordovician and Silurian (Sun et al. 2008; Long et al. 2009). 


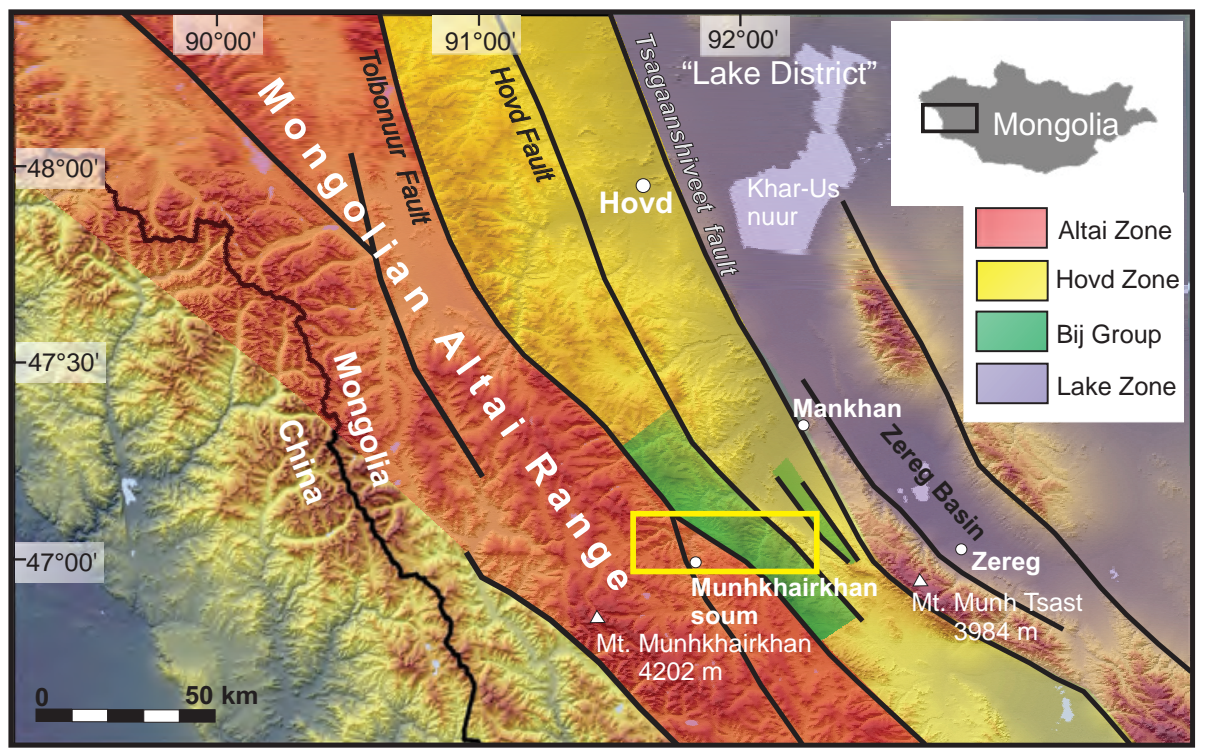

Fig. 1 Map showing the general geological structure of the western Mongolian Altai Range with topography. Study area is marked by yellow rectangle. The major geological units and faults are after Badarch et al. (2002) and Nissen et al. (2009), modified after Dumicz (1977), Don (1977), and Žáček et al. (2017a).

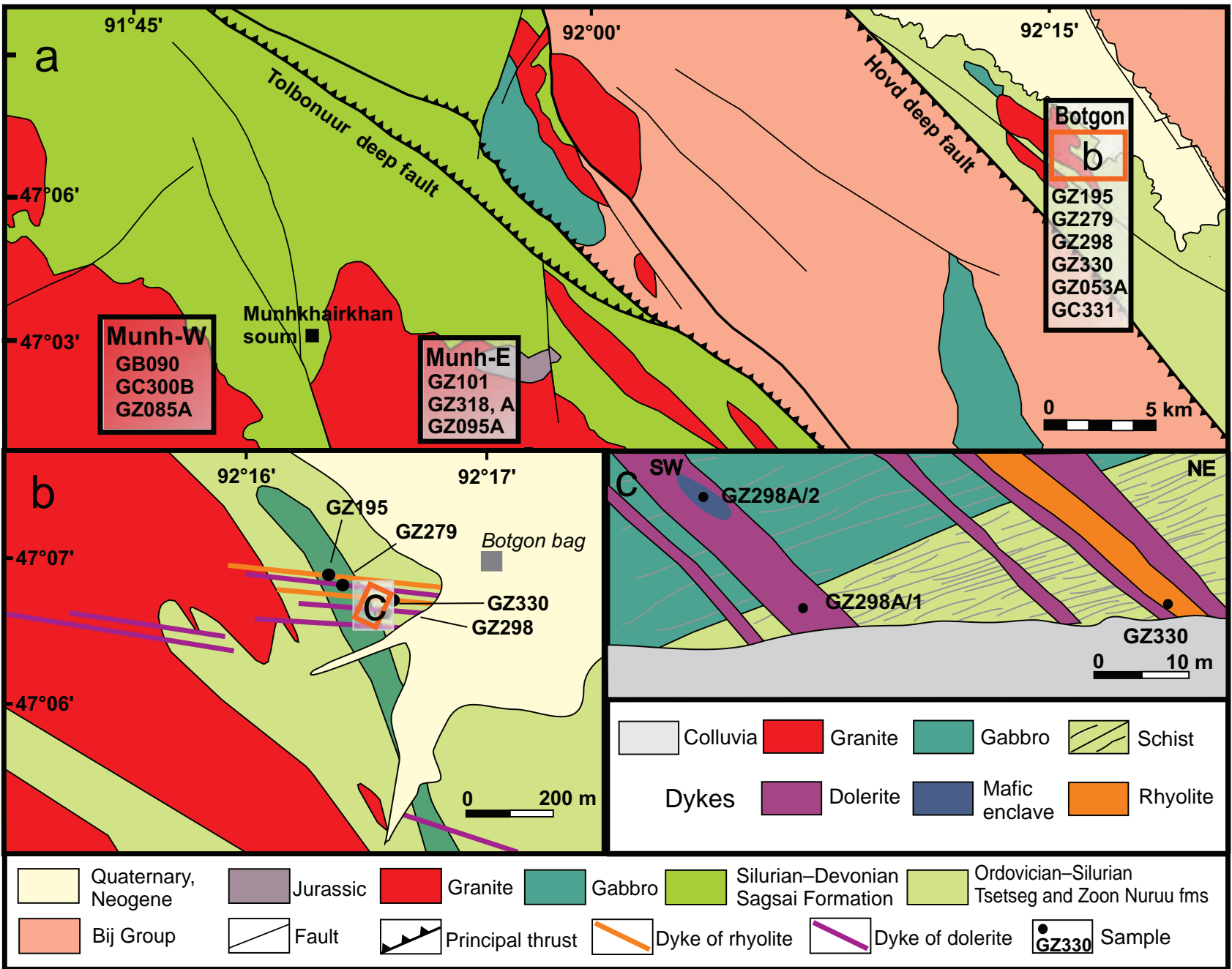

Fig. 2 Geological sketches of the study area modified from the recent geological maps of the Czech Geological Survey (Žáček et al. 2017a, b). Sample localities are also shown. $\mathbf{a}$-Schematic geological map of the area with marked approximate positions of the three most expressive dyke swarms discussed in the text. $\mathbf{b}$ - Detailed geological map of the Botgon dyke swarm area. c - Schematic picture of the exposure (its place is marked in the Fig. $2 b$ by orange rectangle) showing mutual relations between dykes of dolerite and alkali rhyolite and position of sampling points. Abbreviations used: Munh-W - Munhkhairkhan-West dyke swarm, Munh-E - Munhkhairkhan-East dyke swarm, Botgon - Botgon dyke swarm, fms - formations. 
A thick sequence of folded Lower Palaeozoic sediments developed mostly in the flysch facies prevails in the Hovd and Altai zones (Fig. 1). The sediments are ascribed to Zuun Nuruu (Ordovician), Tsetseg (Silurian) and Sagsai (Lower Devonian) formations (Soejono et al. 2018). The age of these sediments decreases generally westwards, but the stratigraphic record is complicated due to strong deformation so that the same part of the sequence may be repeated (Žáček et al. 2017a). Wide contact metamorphic aureoles are developed especially in the western part of the research area, where the sediments were intruded by the huge granitic Zuun Bulgan Pluton of Late Devonian age. The sequence of the above-mentioned Lower Palaeozoic sediments contains two large slices of the Bij Group (Žáček et al. 2017a). Their extent out of the mapped territory remains unclear (Fig. 1). This metamorphic unit consists of a complex of volcanic and sedimentary rocks of Cambrian to Early Ordovician ages, which were intruded by gabbros, diorites to granites of mid-Ordovician age (Soejono et al. 2017). The entire unit subsequently underwent an Early Devonian metamorphism reaching up to amphibolite-facies conditions and polyphase deformation. Finally, it was exhumed along deep-seated, NW-SE striking faults (Soejono et al. 2018).

The youngest units are folded Lower Carboniferous siliciclastic sedimentary rocks, locally preserved unfolded Jurassic sedimentary rocks and Neogene and Quaternary sediments preserved in the intra-mountain basins.

\section{Methods}

\subsection{Field work}

Field work was carried out in 2013-2015 (for details see Žáček et al. 2017a, b) when relevant samples were collected and structural data were documented. A KT-10 kappameter was used to measure the magnetic susceptibility in the field. Location and description of the studied samples are given in Fig. 2 and Tab. 1.

\subsection{Whole-rock geochemistry}

The whole-rock analyses were performed in Activation Laboratories (ActLabs; Toronto, Canada) using the 4Lithoresearch procedure (http://www.actlabs.com). Major-element concentrations were determined by inductively-coupled plasma optical emission spectrometry (ICP-OES), and trace-element concentrations by inductively-coupled plasma mass spectrometry (ICP-MS). The dissolution of the rock powders in both cases followed fusion with a $\mathrm{LiBO}_{2} / \mathrm{Li}_{2} \mathrm{~B}_{4} \mathrm{O}_{7}$ flux. Geochemical data were recalculated and plotted using the GCDkit software package (Janoušek et al. 2006). The mixing of magma, fractional crystallization (FC) and assimilation and fractional crystallization (AFC) processes were modelled using a MS Excel FC-AFC-FCA and mixing modeler (Ersoy and Helvaci 2010). The whole-rock analyses are summarized in Tab. 2.

\subsection{Electron-microprobe analyses (EMPA)}

Electron-microprobe analyses of minerals were carried out using a Cameca SX-100 electron microprobe in the Joint Laboratory of the Masaryk University and the Czech Geological Survey in Brno. The minerals were measured under the following conditions: accelerating voltage $15 \mathrm{kV}$, beam current $10 \mathrm{nA}$ and beam diameter 3-8 $\mu \mathrm{m}$. Natural minerals and stable synthetic compounds were used as standards. Peak-counting times were 10 and $20 \mathrm{~s}$ for major elements and 30 and $40 \mathrm{~s}$ for minor to trace elements. Raw intensities were processed by $X-\varphi$ matrix correction (Merlet 1994). Number of cations of analysed minerals (tables with mineral chemistry are given in Electronic Supplementary Material, ESM) are based on the following numbers of oxygen atoms or $\left(\mathrm{O}+\mathrm{OH}_{\text {calc }}+\mathrm{F}+\mathrm{Cl}\right)$ per formula unit: feldspars $-8 \mathrm{O}$, clinopyroxene $-6 \mathrm{O}$, amphiboles $-22 \mathrm{O}, 2\left(\mathrm{OH}_{\text {calc }}+\mathrm{F}\right.$ $+\mathrm{Cl})$, micas and prehnite $-10 \mathrm{O}, 2\left(\mathrm{OH}_{\text {calc }}+\mathrm{F}+\mathrm{Cl}\right)$, chlorite $-10 \mathrm{O}, 8\left(\mathrm{OH}_{\text {calc }}\right)$, epidote $-12 \mathrm{O}, 1\left(\mathrm{OH}_{\text {calc }}+\mathrm{F}\right)$, titanite $-5 \mathrm{O}$, ilmenite $-3 \mathrm{O}$ and rutile $-2 \mathrm{O}$. All iron is assumed as divalent, in epidote all as trivalent. Mineral abbreviations are after Kretz (1983).

\subsection{K-Ar geochronology}

Age determination was made by the conventional $\mathrm{K}-\mathrm{Ar}$ method at ATOMKI, Debrecen, Hungary. On the basis of the thin section inspection, the most suitable samples were selected and prepared at the laboratories of the Czech Geological Survey in Prague. After crushing, the whole-rock fraction of $0.125-0.30 \mathrm{~mm}(50-100 \mathrm{~g})$ was washed in distilled water, in acetic acid to remove possible $\mathrm{CaCO}_{3}$, then washed again several times in distilled water, and subsequently dried at $40{ }^{\circ} \mathrm{C}$.

Approximately $0.05 \mathrm{~g}$ of finely pulverised sample were digested in acids $\left(\mathrm{HF}, \mathrm{HNO}_{3}\right.$ and $\mathrm{H}_{2} \mathrm{SO}_{4}$ ) in Teflon beakers and finally dissolved in $0.2 \mathrm{M} \mathrm{HCl}$. Potassium was determined by flame photometry with a $\mathrm{Na}$ buffer and $\mathrm{Li}$ internal standard using an Industrial M420 type flame photometer. Multiple runs of inter-laboratory standards (Asia1/95, LP-6, HD-B1, GL-0) indicated the accuracy and reproducibility of this method to be within $2 \%$.

Approximately $0.5 \mathrm{~g}$ of the sample was wrapped in an aluminium foil and copper sieve preheated for about $24 \mathrm{~h}$ at $150-180^{\circ} \mathrm{C}$ in a vacuum. Argon was extracted under ultra-high vacuum conditions by high frequency induction heating and fusion of rock samples in Mo crucibles. 


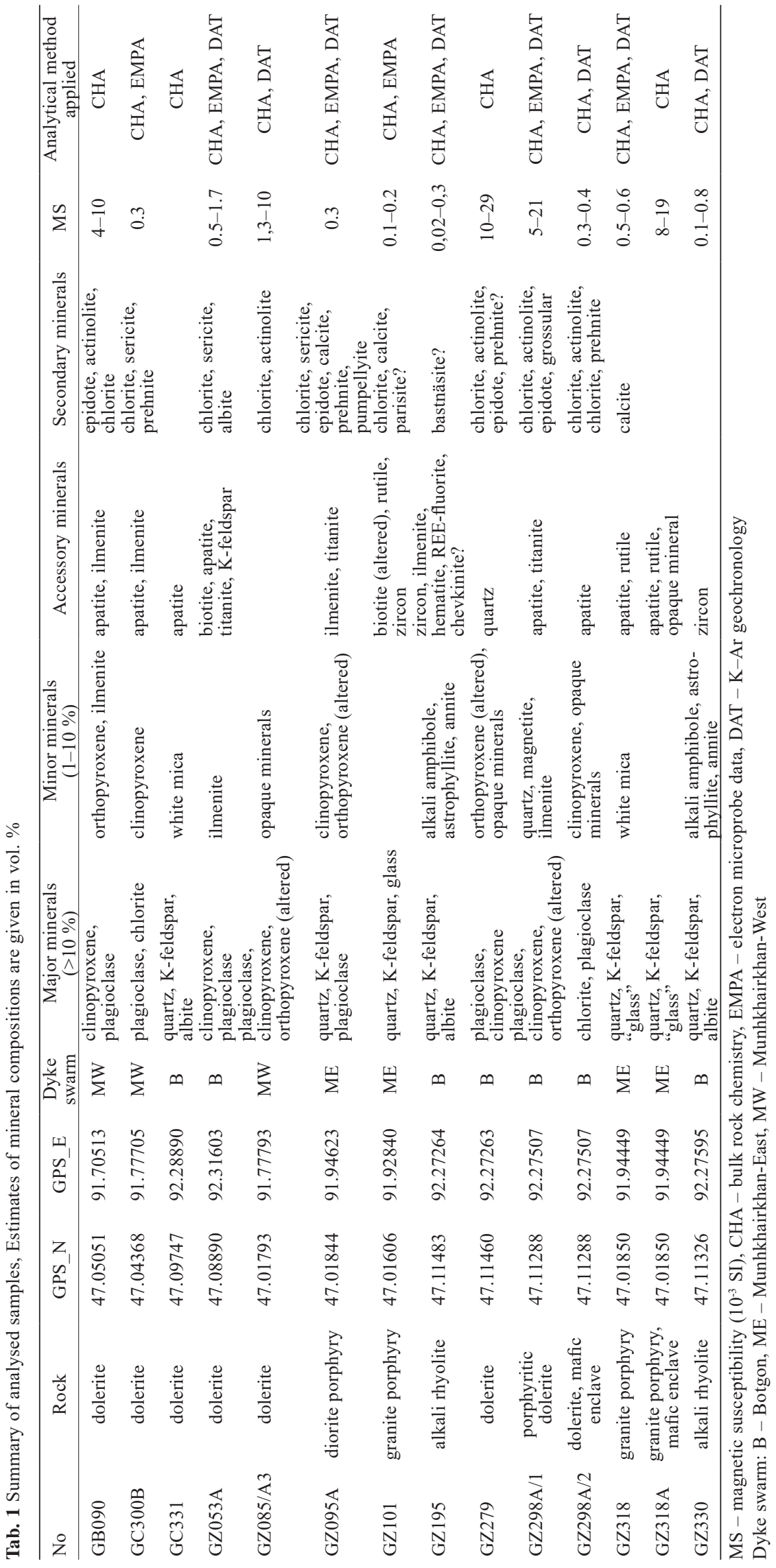

The extracted gases were purified by Ti sponge and SAES St 707 type getters, to remove chemically active gas contaminants. In addition, liquid nitrogen was used in a cold trap to remove condensable gases. The extraction line and cleaning system were linked directly to the mass spectrometer $\left(90^{\circ}\right.$ magnetic sector type, $155 \mathrm{~mm}$ radius, equipped with a Faraday cup, made in Atomki, Debrecen, Hungary), running in static mode.

Argon isotope ratios were measured by the stable isotope dilution method, using a ${ }^{38} \mathrm{Ar}$ spike previously calibrated with atmospheric argon and international rock standards.

Experimental details and results of calibration have been described by Balogh (1985). The age of the samples is calculated using the decay constants suggested by Steiger and Jäger (1977). Analytical error is given at a $68 \%$ confidence level $(1 \sigma)$ using the equation of Cox and Dalrymple (1967). K-Ar geochronology data are presented in Tab. 3 .

Fig. 3 Field photographs depicting different dyke appearances. a - Dolerite dyke $(\sim 5 \mathrm{~m}$ thick) cutting the porphyritic Devonian granite of the Altai Complex in the Munhkhairkhan-west area (point GZ085A, front view to the SW). The arrow shows where the dating sample (GZ085A/3) was taken. b - Dolerite (sample GZ085A/3) collected from the centre of the dyke shown in the picture (a). c - Dyke of diorite porphyry $\sim 14 \mathrm{~m}$ thick cutting the pinkish medium-grained Devonian granite at Dood ulaan govi in the Munhkhairkhan-east area (point GZ095, front view to the west). Note the glacier in the main ridge of the Mongolian Altai dominated by Mt. Munhkhairkhan $(4,204 \mathrm{~m})$. d - Diorite porphyry (sample GZ095A) collected from the centre of the dyke. $\mathbf{e}$ - The dyke of granite porphyry $\sim 6 \mathrm{~m}$ thick (dark rocky wall, point GZ318, front view to the west), which is parallel to the dyke of diorite porphyry (GZ095) and situated $\sim 200 \mathrm{~m}$ to the WNW. f - Granite porphyry GZ318. g - The dyke of alkali rhyolite $\sim 4 \mathrm{~m}$ thick (point GZ330, front view to the west) cutting the biotite schist to hornfels of the Tsetseg and Zoon Nuruu formations of the Ordovician to Silurian age in the area of Botgon, see also Figs $2 b-c$. $\mathbf{h}$ - Alkali rhyolite with accessory alkali amphibole and astrophyllite (sample GZ330). 

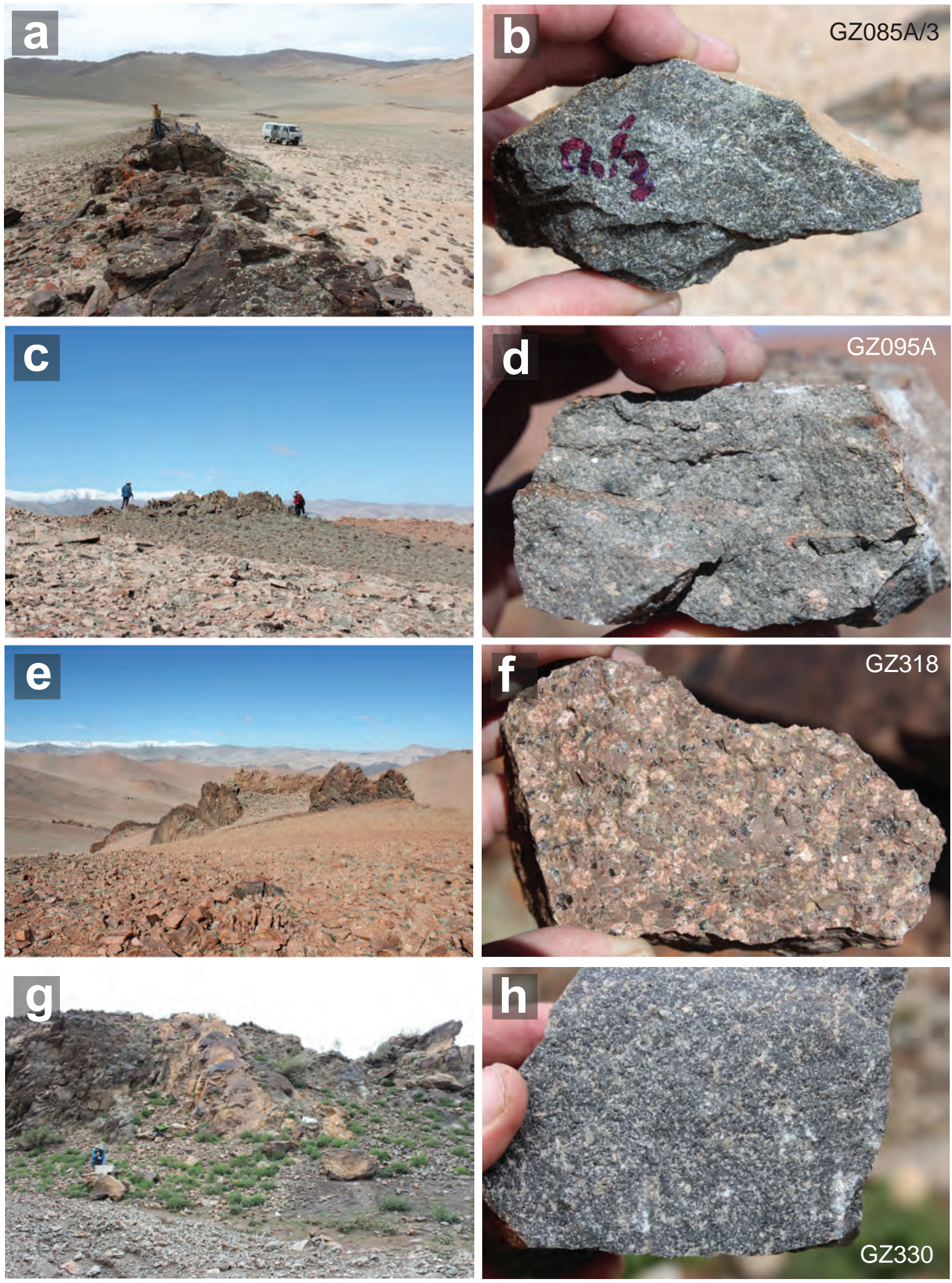
Tab. 2 Whole-rock analyses of studied dykes (wt. \%, ppm)

\begin{tabular}{|c|c|c|c|c|c|c|c|c|c|c|c|c|c|c|}
\hline sample & GZ195 & GZ101 & GZ318 & GZ330 & GC331 & GZ318A & GZ095a & GZ298A/1 & GZ298A/2 & GB090 & GC300B & GZ053A & GZ085/3 & GZ279 \\
\hline $\mathrm{SiO}_{2}$ & 75.52 & 73.09 & 74.95 & 75.93 & 77.25 & 58.08 & 61.06 & 52.02 & 50.28 & 47.07 & 46.34 & 44.39 & 47.48 & 47.69 \\
\hline $\mathrm{Al}_{2} \mathrm{O}_{3}$ & 11.63 & 12.57 & 12.32 & 11.77 & 11.66 & 16.27 & 15.55 & 15.84 & 15.34 & 16.61 & 15.20 & 14.63 & 15.43 & 15.35 \\
\hline $\mathrm{Fe}_{2} \mathrm{O}_{3} \mathrm{t}$ & 1.98 & 3.53 & 2.29 & 2.23 & 1.86 & 6.27 & 6.13 & 11.55 & 12.82 & 10.82 & 12.83 & 14.90 & 13.27 & 14.62 \\
\hline $\mathrm{MnO}$ & 0.03 & 0.10 & 0.07 & 0.03 & 0.03 & 0.50 & 0.12 & 0.17 & 0.19 & 0.17 & 0.20 & 0.22 & 0.20 & 0.21 \\
\hline $\mathrm{MgO}$ & 0.11 & 0.25 & 0.18 & 0.01 & 0.09 & 3.62 & 3.16 & 4.28 & 5.06 & 7.43 & 6.81 & 6.04 & 6.77 & 5.30 \\
\hline $\mathrm{CaO}$ & 0.37 & 0.23 & 0.48 & 0.26 & 0.42 & 3.22 & 4.81 & 7.10 & 5.86 & 10.44 & 9.82 & 8.45 & 10.21 & 6.95 \\
\hline $\mathrm{Na}_{2} \mathrm{O}$ & 3.94 & 3.57 & 1.25 & 4.35 & 3.55 & 4.55 & 4.36 & 3.60 & 4.20 & 2.43 & 3.09 & 2.99 & 2.42 & 3.50 \\
\hline $\mathrm{K}_{2} \mathrm{O}$ & 4.49 & 4.26 & 7.24 & 4.43 & 4.51 & 3.22 & 1.71 & 1.20 & 1.53 & 0.42 & 0.43 & 0.94 & 0.40 & 1.31 \\
\hline $\mathrm{TiO}_{2}$ & 0.13 & 0.20 & 0.10 & 0.09 & 0.11 & 0.86 & 0.78 & 2.16 & 2.26 & 1.67 & 2.25 & 3.22 & 2.27 & 2.79 \\
\hline $\mathrm{P}_{2} \mathrm{O}_{5}$ & 0.01 & 0.05 & 0.02 & $<0.01$ & 0.03 & 0.20 & 0.22 & 0.36 & 0.39 & 0.27 & 0.28 & 0.58 & 0.30 & 0.48 \\
\hline LOI & 0.62 & 0.77 & 0.89 & 0.04 & 0.19 & 3.40 & 2.58 & 2.03 & 2.72 & 2.14 & 3.21 & 3.19 & 1.76 & 2.02 \\
\hline Total & 98.82 & 98.61 & 99.80 & 99.16 & 99.69 & 100.20 & 100.50 & 100.30 & 100.70 & 99.48 & 100.50 & 99.53 & 100.50 & 100.20 \\
\hline $\mathrm{A} / \mathrm{CNK}$ & 0.97 & 1.15 & 1.14 & 0.95 & 1.02 & 0.97 & 0.88 & 0.79 & 0.80 & 0.71 & 0.65 & 0.69 & 0.67 & 0.77 \\
\hline $\mathrm{A} / \mathrm{NK}$ & 1.03 & 1.20 & 1.25 & 0.98 & 1.09 & 1.48 & 1.72 & 2.19 & 1.79 & 3.73 & 2.74 & 2.46 & 3.50 & 2.14 \\
\hline $\mathrm{Na}_{2} \mathrm{O}+\mathrm{K}_{2} \mathrm{O}$ & 8.43 & 7.83 & 8.49 & 8.78 & 8.06 & 7.77 & 6.07 & 4.80 & 5.73 & 2.85 & 3.52 & 3.93 & 2.82 & 4.81 \\
\hline $\mathrm{K}_{2} \mathrm{O} / \mathrm{MgO}$ & 40.82 & 17.04 & 40.22 & 443.00 & 50.11 & 0.89 & 0.54 & 0.28 & 0.30 & 0.06 & 0.06 & 0.16 & 0.06 & 0.25 \\
\hline $\bar{Y}$ & 92.6 & 33.5 & 33.5 & 109.0 & 47.1 & 22.7 & 28.0 & 43.5 & 41.3 & 29.5 & 33.4 & 37.8 & 34.3 & 41.8 \\
\hline $\mathrm{La}$ & 37.0 & 40.0 & 28.1 & 39.6 & 37.3 & 21.6 & 20.4 & 29.0 & 25.3 & 11.0 & 13.2 & 23.7 & 14.6 & 25.1 \\
\hline $\mathrm{Ce}$ & 90.1 & 73.3 & 53.7 & 94.0 & 84.4 & 43.0 & 44.6 & 63.3 & 57.3 & 27.0 & 31.1 & 53.3 & 34.4 & 56.9 \\
\hline $\operatorname{Pr}$ & 10.9 & 8.0 & 6.2 & 11.3 & 9.7 & 4.8 & 5.2 & 7.8 & 7.1 & 3.9 & 4.5 & 7.1 & 4.6 & 7.5 \\
\hline $\mathrm{Nd}$ & 41.2 & 27.7 & 22.0 & 42.8 & 33.5 & 18.5 & 20.2 & 32.7 & 30.5 & 17.8 & 20.7 & 31.6 & 21.5 & 31.0 \\
\hline $\mathrm{Sm}$ & 11.8 & 5.5 & 4.9 & 12.4 & 7.7 & 4.0 & 4.6 & 7.6 & 7.4 & 5.1 & 5.4 & 7.5 & 5.8 & 7.2 \\
\hline $\mathrm{Eu}$ & 0.2 & 0.5 & 0.3 & 0.1 & 0.2 & 1.2 & 1.2 & 2.0 & 2.2 & 1.8 & 1.8 & 2.5 & 2.0 & 2.5 \\
\hline Gd & 12.8 & 4.9 & 4.6 & 14.4 & 7.0 & 4.2 & 4.5 & 7.9 & 7.5 & 5.5 & 6.3 & 7.5 & 6.3 & 7.8 \\
\hline $\mathrm{Tb}$ & 2.62 & 0.82 & 0.80 & 2.85 & 1.19 & 0.63 & 0.75 & 1.27 & 1.16 & 0.95 & 1.09 & 1.24 & 1.03 & 1.23 \\
\hline Dy & 16.6 & 5.2 & 5.2 & 18.7 & 7.7 & 4.0 & 4.7 & 7.7 & 7.4 & 5.7 & 6.2 & 6.9 & 6.2 & 7.6 \\
\hline Ho & 3.29 & 0.99 & 1.06 & 3.73 & 1.57 & 0.81 & 0.94 & 1.56 & 1.47 & 1.13 & 1.20 & 1.41 & 1.22 & 1.47 \\
\hline $\mathrm{Er}$ & 9.98 & 2.95 & 3.21 & 11.20 & 4.78 & 2.42 & 2.79 & 4.49 & 4.08 & 3.08 & 3.38 & 3.82 & 3.35 & 4.18 \\
\hline $\mathrm{Tm}$ & 1.64 & 0.48 & 0.49 & 1.63 & 0.74 & 0.34 & 0.40 & 0.63 & 0.58 & 0.47 & 0.53 & 0.53 & 0.50 & 0.59 \\
\hline $\mathrm{Yb}$ & 10.4 & 3.5 & 3.6 & 10.6 & 4.9 & 2.2 & 2.6 & 4.2 & 3.9 & 2.8 & 3.4 & 3.3 & 3.1 & 3.9 \\
\hline $\mathrm{Lu}$ & 1.54 & 0.54 & 0.57 & 1.53 & 0.80 & 0.36 & 0.40 & 0.62 & 0.64 & 0.43 & 0.51 & 0.49 & 0.50 & 0.60 \\
\hline $\mathrm{Eu} / \mathrm{Eu}^{*}$ & 0.05 & 0.31 & 0.21 & 0.03 & 0.09 & 0.90 & 0.81 & 0.79 & 0.90 & 1.04 & 0.96 & 1.02 & 1.00 & 1.00 \\
\hline $\mathrm{La}_{\mathrm{N} /} \mathrm{Yb}_{\mathrm{N}}$ & 2.40 & 7.79 & 5.28 & 2.52 & 5.09 & 6.77 & 5.29 & 4.68 & 4.41 & 2.65 & 2.66 & 4.87 & 3.19 & 4.29 \\
\hline $\mathrm{La}_{\mathrm{N}} / \mathrm{Sm}_{\mathrm{N}}$ & 1.97 & 4.59 & 3.59 & 2.01 & 3.05 & 3.37 & 2.81 & 2.41 & 2.14 & 1.36 & 1.53 & 2.00 & 1.58 & 2.18 \\
\hline$\Sigma$ REE & 250 & 174 & 135 & 265 & 202 & 108 & 113 & 171 & 157 & 87 & 99 & 151 & 105 & 158 \\
\hline
\end{tabular}

\section{Results}

\subsection{Field observations}

The studied samples were taken from dykes, which cut the host rocks with apparent discordancy (Fig. 3a, c, $\mathrm{e}, \mathrm{g})$. The distribution of the dykes is highly irregular; locally they compose conspicuous dyke swarms. The most expressive dyke swarms crop out SW and E of Munhkhairkhan soum, in the surroundings of the Botgon bag and further upstream on the flanks of the Yavakh Bolotzootoy Valley (Fig. 2b-c). The dykes are subvertical or steeply dipping (Fig. 3e, g). The prevailing orientations of the dykes are NE-SW in the surroundings of Munhkhairkhan and $\mathrm{E}-\mathrm{W}$ in the Botgon bag area. Their thickness varies between 0.5 and $20 \mathrm{~m}$, and their length ranges from several tens of meters to $\sim 2.5 \mathrm{~km}$.

\subsubsection{Munhkhairkhan West dyke swarm}

This dyke swarm comprises several tens of dolerite dykes and occupies a vast area to the SW of Munhkhairkhan soum (Fig. 2a). A few isolated dykes also occur west of this soum. The dykes belonging to this swarm display a thickness of $\sim 2-20 \mathrm{~m}$, length of $\sim 300-2,000 \mathrm{~m}$ and strike NE-SW to ENE-WSW. The dykes cut the Late Devonian granite (Zuun Bulgan Pluton) of the Altai Complex and Lower Palaeozoic sediments in the contact aureole of this pluton. Studied dykes are missing in the Bij Group.

\subsubsection{Munhkhairkhan East dyke swarm}

This swarm is situated $\sim 6-8 \mathrm{~km}$ ESE of the Munhkhairkhan soum in a place called Dood ulaan govi. There are several dykes of granite porphyry and one dyke of diorite porphyry that cut the Devonian granite of the 
Tab. 2 Continued

\begin{tabular}{|c|c|c|c|c|c|c|c|c|c|c|c|c|c|c|}
\hline sample & GZ195 & GZ101 & GZ318 & GZ330 & GC331 & GZ318A C & JZ095a & GZ298A/1 & GZ298A/2 & GB090 & GC300B & GZ053A G & ZZ085/3 & GZ279 \\
\hline $\mathrm{Cs}$ & 6.2 & 2.8 & 4.7 & 4.7 & 1.2 & 2.7 & 1.5 & 0.6 & 0.7 & 16.0 & 4.4 & 1.7 & 14.9 & 0.5 \\
\hline $\mathrm{Rb}$ & 207 & 179 & 291 & 207 & 176 & 143 & 60 & 31 & 40 & 42 & 24 & 20 & 32 & 36 \\
\hline $\mathrm{Sr}$ & 14 & 125 & 80 & 3 & 26 & 429 & 305 & 358 & 317 & 276 & 363 & 406 & 268 & 348 \\
\hline $\mathrm{Ba}$ & 40 & 1371 & 1621 & 11 & 47 & 1056 & 355 & 278 & 268 & 72 & 76 & 470 & 133 & 273 \\
\hline $\mathrm{Be}$ & 9 & 1 & 2 & 9 & 6 & 2 & 2 & 3 & 2 & 1 & 1 & 2 & 2 & 2 \\
\hline $\mathrm{Th}$ & 23.8 & 12.5 & 14.3 & 18.9 & 24.8 & 4.16 & 4.65 & 4.37 & 3.83 & 0.65 & 0.89 & 1.99 & 0.89 & 2.55 \\
\hline $\mathrm{U}$ & 4.5 & 2.64 & 2.6 & 4.21 & 4.62 & 1.1 & 1.22 & 0.82 & 0.72 & 0.22 & 0.55 & 0.62 & 0.32 & 0.63 \\
\hline $\mathrm{Zr}$ & 422 & 144 & 112 & 375 & 137 & 144 & 163 & 285 & 257 & 137 & 171 & 224 & 196 & 251 \\
\hline Hf & 14.0 & 3.2 & 2.8 & 10.9 & 4.0 & 2.7 & 3.3 & 4.9 & 4.9 & 3.4 & 3.7 & 5.0 & 3.7 & 4.7 \\
\hline $\mathrm{Nb}$ & 82.6 & 6.1 & 6.8 & 53.3 & 16.9 & 8.1 & 8.2 & 19.8 & 13.9 & 7.5 & 9.3 & 25.5 & 8.2 & 20.5 \\
\hline $\mathrm{Ta}$ & 7.61 & 0.88 & 1.14 & 6.12 & 2.63 & 0.66 & 0.75 & 1.65 & 1.08 & 0.59 & 0.65 & 1.84 & 0.61 & 1.61 \\
\hline $\mathrm{Pb}$ & 43 & 36 & 13 & 32 & 19 & 43 & 13 & 5 & 7 & $<5$ & $<5$ & $<5$ & $<5$ & 8 \\
\hline $\mathrm{Bi}$ & 0.2 & 0.1 & $<0.1$ & 0.2 & $<0.1$ & 0.4 & $<0.1$ & 0.2 & 0.1 & $<0.1$ & $<0.1$ & $<0.1$ & $<0.1$ & $<0.1$ \\
\hline $\mathrm{Cu}$ & 20 & $<10$ & $<10$ & $<10$ & $<10$ & $<10$ & 30 & 20 & 20 & 50 & 50 & 40 & 50 & 20 \\
\hline $\mathrm{Zn}$ & 190 & 120 & 100 & 170 & $<30$ & 980 & 110 & 110 & 120 & 80 & 100 & 140 & 100 & 130 \\
\hline Mo & $<2$ & $<2$ & $<2$ & $<2$ & 3 & $<2$ & $<2$ & $<2$ & $<2$ & $<2$ & $<2$ & $<2$ & $<2$ & $<2$ \\
\hline As & 28 & $<5$ & $<5$ & $<5$ & 20 & $<5$ & $<5$ & 13 & 18 & $<5$ & $<5$ & 40 & $<5$ & 16 \\
\hline $\mathrm{Sn}$ & 18 & 8 & 2 & 11 & 3 & 4 & 2 & 3 & 2 & 1 & 2 & 2 & 1 & 3 \\
\hline $\mathrm{V}$ & 10 & 10 & 5 & $<5$ & 7 & 100 & 91 & 217 & 238 & 223 & 302 & 361 & 281 & 290 \\
\hline $\mathrm{Cr}$ & 90 & $<20$ & $<20$ & $<20$ & $<20$ & 60 & 60 & 40 & 30 & 130 & 110 & 70 & 90 & 30 \\
\hline $\mathrm{Co}$ & $<1$ & 2 & $<1$ & $<1$ & $<1$ & 20 & 18 & 32 & 34 & 43 & 46 & 50 & 47 & 43 \\
\hline $\mathrm{Ni}$ & $<20$ & $<20$ & $<20$ & $<20$ & $<20$ & 20 & 30 & 20 & $<20$ & 90 & 60 & 80 & 50 & 30 \\
\hline $\mathrm{Sc}$ & $<1$ & 4 & 3 & $<1$ & 2 & 16 & 14 & 22 & 26 & 35 & 38 & 29 & 37 & 27 \\
\hline In & $<0.1$ & $<0.1$ & $<0.1$ & 0.1 & $<0.1$ & $<0.1$ & $<0.1$ & $<0.1$ & $<0.1$ & $<0.1$ & $<0.1$ & $<0.1$ & $<0.1$ & 0.1 \\
\hline $\mathrm{Sb}$ & 0.6 & 0.8 & 0.5 & $<0.2$ & $<0.2$ & 0.8 & 0.3 & 4.3 & 6.7 & 0.4 & 0.6 & 1.0 & $<0.2$ & 2.3 \\
\hline $\mathrm{Ga}$ & 36 & 17 & 14 & 32 & 21 & 17 & 18 & 23 & 22 & 19 & 23 & 23 & 21 & 24 \\
\hline W & $<0.5$ & 3.0 & 0.8 & 1.2 & 0.8 & 0.7 & 2.3 & $<0.5$ & $<0.5$ & $<0.5$ & $<0.5$ & $<0.5$ & 1.6 & $<0.5$ \\
\hline $\mathrm{Tl}$ & 1.0 & 1.3 & 2.3 & 0.9 & 0.5 & 1.3 & 0.4 & 0.1 & 0.2 & 0.5 & 0.2 & 0.2 & 0.3 & 0.1 \\
\hline
\end{tabular}

Altai Complex and Lower Palaeozoic sediments in the contact aureole of this pluton. The dykes strike N-S or NNE-SSW, they have a thickness of $\sim 5-15 \mathrm{~m}$ and a length of $1,000-2,500 \mathrm{~m}$.

\subsubsection{Botgon dyke swarm}

This area can be found at Botgon bag situated in the Yavakh Boolotzootoy Valley (Fig. 2b). Scattered dolerite dykes also occur upstream of this valley to the SE (not visible in Fig. 2). The swarm includes several tens of dolerite dykes (0.5-20 m thick) and four dykes of alkali rhyolite $(2 \times 0.5 \mathrm{~m}, 3 \mathrm{~m}$ and $4-5 \mathrm{~m}$ thick $)$. The dykes have a WNW-ESE strike and cross-cut Lower Palaeozoic biotite schists (to hornfelses), quartzites, marbles, and gabbro of the Hovd Zone and the small granite pluton of Early Carboniferous age (Fig. 2b-c).

\subsection{Petrography and mineral chemistry}

Four different types of dykes were distinguished in the field - dolerite, diorite porphyry, granite porphyry and alkali rhyolite (Fig. 3). They are described in detail below. Mineral assemblages are summarized in Tab. 1 and the tables of mineral chemistry are given in Electronic Supplementary Material.

\subsubsection{Dolerite (basaltic andesite to basalt)}

Dolerite (Fig. 3b) is a hard, irregularly jointed rock of nearly black colour and randomly oriented fine-grained structure. Sometimes it contains up to $1 \mathrm{~cm}$ big vesicles, empty or infilled by chlorite. All dolerite dykes underwent late magmatic or post-magmatic alteration, and as a consequence parts of the primary minerals have been replaced by secondary ones (chlorite, white mica or clay minerals).

On microscale, the rock has ophitic texture and is composed of groundmass $(<0.2-1.5 \mathrm{~mm})$ and up to $2 \mathrm{~mm}$-sized phenocrysts (up to $\sim 25-30 \%$ ) of clinopyroxene and plagioclase, rarely also amphibole, orthopyroxene and olivine (Fig. $4 \mathrm{a}-\mathrm{b}$ and Tab. 1). Clinopyroxene is pink to violet, mostly fresh, plagioclase is commonly sericitised, orthopyroxene and olivine are mostly completely replaced by secondary minerals, mainly chlorite, possibly also by talc. 

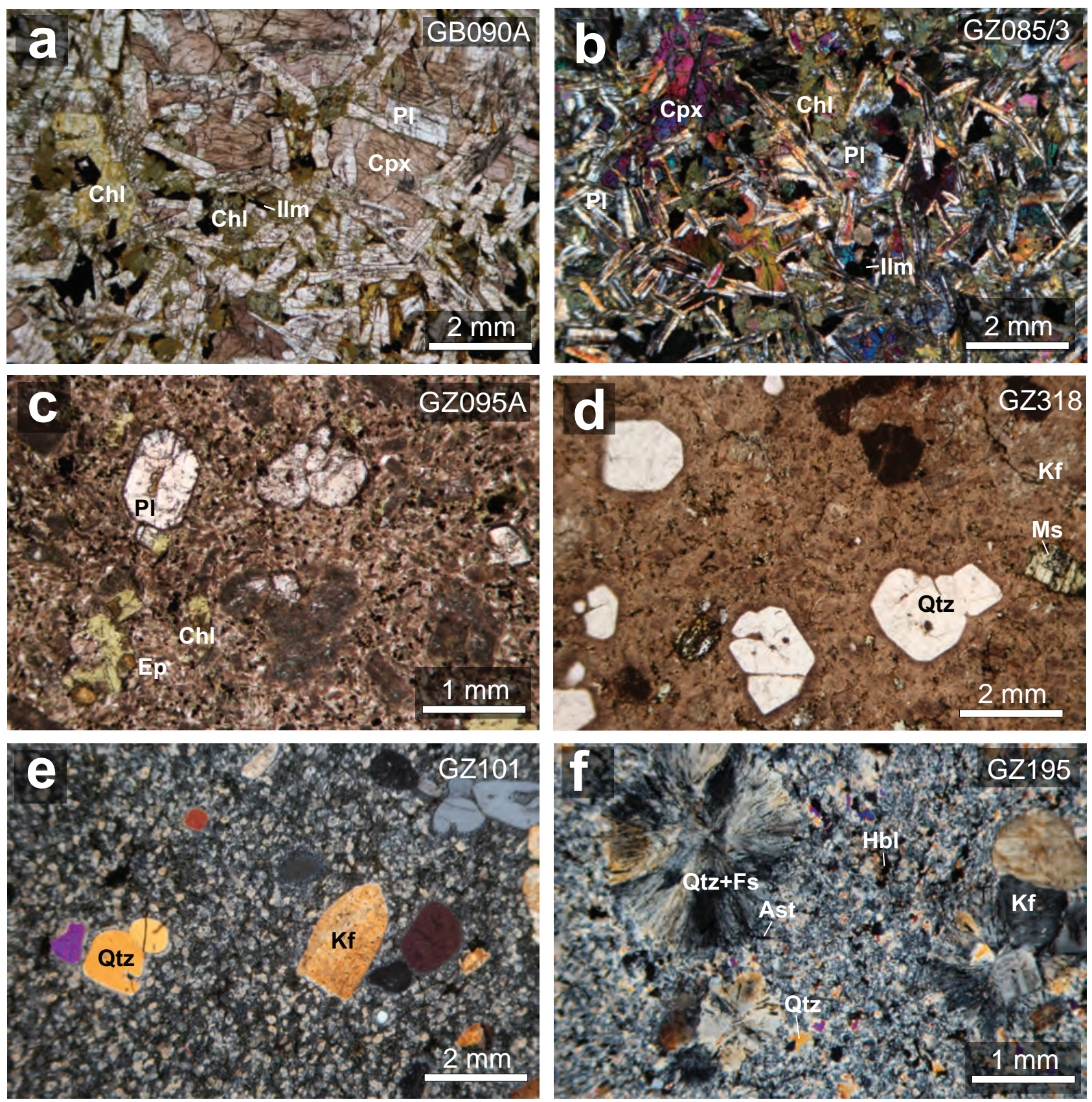

Fig. 4 Photomicrographs of studied samples of dykes in plane-polarised light (a, c, d) and with crossed polarisers (b, e, f). a - Dolerite from dyke (sample GB090A) situated between Ikh Khar and Dund Khar in the Munhkhairkhan-west area. b - Dolerite (sample GZ085A/3) taken from the centre of the dyke in the Munhkhairkhan-west area (see Fig. 3a-b). Both samples display similar ophitic texture with unaltered phenocrysts of plagioclase and clinopyroxene; orthopyroxene and possibly also olivine are completely replaced by chlorite. c - Diorite porphyry (sample GZ095A) from the Munhkhairkhan-east area. The rock contains relatively fresh phenocrysts of plagioclase, the mafic components converted to secondary minerals, mainly chlorite, and clouded fine-grained matrix. See also Fig. 3c-d. d - Granite porphyry (sample GZ318) from the Munhkhairkhan-east area (see Fig. 3e-f). The rock contains phenocrysts of quartz, white mica and altered potassium feldspar and probable clinopyroxene or biotite. The rest is a brownish fine-grained matrix, which represents devitrified glass. e - Granite porphyry (sample GZ101) from the Munhkhairkhan-east area. Note phenocrysts of quartz and potassium feldspar and fine-grained devitrified matrix. f - Alkali rhyolite (sample GZ195) taken from the centre of the 3 m-thick dyke in the Botgon area (see Fig 2 and Žáček et al. 2016). The rock contains dominant quartz and alkali feldspars and abundant tiny inclusions of alkali amphibole, astrophyllite and annite. The rock shows spherulites and micrographic (granophyric) texture due to rapid cooling of the melt.

Porphyritic facies of dolerite occurs in the dyke swarm near Botgon bag (Fig. 2). The dolerites have a fine- to medium-grained groundmass with scattered plagioclase phenocrysts $0.5-2.0 \mathrm{~cm}$ long (up to $\sim 15$ vol. \%). In sever- al dykes there are irregular (dm-m sized) mafic enclaves, more fine-grained with a smaller portion of plagioclase. Abundant pseudomorphs after olivine and orthopyroxene are partly to completely replaced by Fe-chlorite. The 
Tab. $3 \mathrm{~K}-$ Ar geochronology results

\begin{tabular}{|c|c|c|c|c|c|c|c|c|c|}
\hline Analytical $\mathrm{N}^{\circ}$ & Sample $N^{o}$ & Dyke/Rock & Swarm & Position & K (wt.\%) & $\begin{array}{c}{ }^{40} \mathrm{Ar}_{\mathrm{rad}} \\
(\mathrm{ccSTP} / \mathrm{g})\end{array}$ & $\begin{array}{c}{ }^{40} \mathrm{Ar}_{\text {rad }} \\
(\%)\end{array}$ & $\begin{array}{c}\mathrm{K}-\mathrm{Ar} \text { age } \\
(\mathrm{Ma})\end{array}$ & $\begin{array}{c}\text { Error } \\
(\mathrm{Ma}, 1 \sigma)\end{array}$ \\
\hline $8584 / 3$ & GZ085/A3 & dolerite & MW & centre & 0.315 & $3.9001 \times 10^{-6}$ & 48.9 & 293.3 & 10.7 \\
\hline 8585 & GZ095A & diorite porphyry & $\mathrm{ME}$ & centre & 1.297 & $1.5309 \times 10^{-5}$ & 70.7 & 280.6 & 8.9 \\
\hline 8589 & GZ318 & granite porphyry & $\mathrm{ME}$ & centre & 5.967 & $7.1160 \times 10^{-5}$ & 78.9 & $288.3 * *$ & 8.8 \\
\hline 8475 & GZ053 & dolerite & B & centre & 0.839 & $9.9944 \times 10^{-6}$ & 82.8 & 283.7 & 8.7 \\
\hline $8588 / 1$ & GZ298A/1 & dolerite & B & centre & 0.937 & $1.1145 \times 10^{-5}$ & 60.8 & 282.6 & 9.4 \\
\hline $8588 / 2$ & GZ298A/2 & dolerite & B & mafic enclave & 1.327 & $1.5703 \times 10^{-5}$ & 74.7 & 281.3 & 8.8 \\
\hline 8477 & GZ195 & alkali rhyolite & B & centre & 3.555 & $4.5086 \times 10^{-5}$ & 90.4 & $299.9 *$ & 9.1 \\
\hline 8592 & GZ330 & alkali rhyolite & B & $\mathrm{rim}-20 \mathrm{~cm}$ & 3.600 & $4.1482 \times 10^{-5}$ & 72.4 & 274.4 & 8.7 \\
\hline
\end{tabular}

*data from Žáček et al. (2016), **average of two measurements

Swarm: B - Botgon, ME - Munhkhairkhan-East, MW - Munhkhairkhan-West

amount of opaque minerals (ilmenite and magnetite) varies between 1 and 7 vol. \%. The magnetic susceptibility of the dolerite dykes is mostly low, $0.30-0.70 \times 10^{-3} \mathrm{SI}$, but some dykes, particularly those of porphyric type near Botgon bag, are more magnetic $\left(4-40 \times 10^{-3} \mathrm{SI}\right.$; Tab. 1). Generally, the inner parts of the large dykes are more magnetic than the margins. Primary minerals include plagioclase $\left(\mathrm{An}_{52-92} ;\right.$ Fig. 5a), clinopyroxene (Ti-rich ferroan diopside-augite, $\mathrm{Si}=1.72-1.92, \mathrm{Ti}=0.02-0.12, \mathrm{Al}$ $=0.12-0.29$ (apfu), $X_{\mathrm{Mg}}=\mathrm{Mg} /\left(\mathrm{Mg}+\mathrm{Fe}^{\text {tot }}\right)=0.60-0.65$; Fig. 5b), orthopyroxene (probably ferroan enstatite), in places amphibole (magnesiohornblende to ferrohornblende, $\mathrm{Si}=6.68-6.74 \mathrm{apfu}, \mathrm{Na}^{\text {tot }} 0.05-0.24 \mathrm{apfu}, \mathrm{X}_{\mathrm{Mg}}$ $0.47-0.50$; Fig. $5 \mathrm{c}$ ) and olivine. Quartz up to 3 vol. $\%$ is also occurs in places. Accessory minerals are biotite ( $\mathrm{Al}$ $=1.1-1.2$ apfu, $\mathrm{X}_{\mathrm{Mg}}=0.30-0.38$; Fig. $\left.5 \mathrm{~d}\right)$, titanite $(0.16$ $\mathrm{Al}$ apfu), ilmenite (4-8 mol. \% of pyrophanite), magnetite $\left(0.36\right.$ wt. $\% \mathrm{TiO}_{2}, 0.17$ wt. $\left.\% \mathrm{Cr}_{2} \mathrm{O}_{3}\right)$ and acicular apatite.

Ferroan chlorite (chamosite, $\mathrm{Si}=2.91-3.06 \mathrm{apfu}, \mathrm{X}_{\mathrm{Mg}}$ $=0.39-0.45$; Fig. $5 \mathrm{e}$ ) and talc are the most abundant secondary minerals that mostly completely replace orthopyroxene and olivine. Less frequent secondary minerals are epidote, albite $\left(\mathrm{An}_{4-8}\right)$, actinolite $\left(\mathrm{Si}=7.51-7.86, \mathrm{X}_{\mathrm{Mg}}\right.$ $=0.42-0.62)$, calcite, antigorite, prehnite, pumpellyite, $\mathrm{K}$-feldspar and hydrous titanian grossular-andradite (0.15-0.64 Ti apfu). Secondary minerals also form infills of vesicles $1-5 \mathrm{~mm}$ across.

\subsubsection{Diorite porphyry}

In the Munhkhairkhan-east area, two-pyroxene diorite porphyry (Fig. 3d) occurs as a single dyke trending NNE-SSW $\left(20^{\circ}\right)$ with a thickness of $c .14$ m (Fig. 3c). Contacts are sharp without alterations, only locally with veinlets of milky quartz with disseminated magnetite. Diorite porphyry is grey, its groundmass is fine-grained with macroscopically apparent isometric phenocrysts of plagioclase and clinopyroxene up to $2 \mathrm{~mm}$ in size; locally appear up to several $\mathrm{mm}$ big amygdales filled by chlorite (Fig. 3d). Clinopyroxene-rich mafic microgranular enclaves, up to $3 \mathrm{~cm}$ long, are locally present.
Microscopically is the diorite porphyry a porphyritic, rock with very fine-grained, randomly oriented groundmass, which shows marks of alteration (Fig. 4c). The rock is jointed with frequent crystalline coatings of epidote. Phenocrysts comprise plagioclase, clinopyroxene, orthopyroxene and, rarely, quartz. Phenocrysts of plagioclase, $0.5-2 \mathrm{~mm}$ long ( $\sim 20 \mathrm{vol} . \%)$, are altered to cloudy, very fine-grained secondary minerals, partly by small grains of sericite, epidote, prehnite and pumpellyite. Some plagioclase phenocrysts are characterised by cores with a sieve-like texture that are overgrown by oscillatory-zoned rims. Meanwhile, other plagioclase phenocrysts consist of oscillatory-zoned cores with resorption rims. Phenocrysts of the original orthopyroxene $(\sim 6$ vol. \%) are mostly completely replaced by a mixture of chlorite and secondary minerals of antigorite group and probably also by talc. Colourless clinopyroxene $\left(\sim 4\right.$ vol. \%) is augite, $\mathrm{X}_{\mathrm{Mg}}=0.79-0.80, \mathrm{Al}=0.10-0.14$ apfu, $\mathrm{Ti}=0.01-0.02 \mathrm{apfu}$ (Fig. 5b) and occurs as fresh rounded phenocrysts $(0.1-0.8 \mathrm{~mm})$ and as tiny prismatic crystals $(0.1 \mathrm{~mm})$ in the rim of quartz xenocrysts $\left(\mathrm{X}_{\mathrm{Mg}}=\right.$ $0.58-0.61, \mathrm{Al}=0.01-0.02$ apfu, $\mathrm{Ti}=0.005 \mathrm{apfu} ;$ Fig. $5 \mathrm{~b}$ ). Accessory titanite contains elevated $\mathrm{Al}=0.24, \mathrm{Fe}=0.07$ and $\mathrm{F}=0.15$ (all apfu).

Groundmass of a granularity $0.03-0.3 \mathrm{~mm}$ contains dominating altered plagioclase under $0.05 \mathrm{~mm}$ in size, $\sim 10$ vol. \% K-feldspar, $\sim 15$ vol. \% of chlorite (clinochlore to penninite with $\mathrm{Si}=3.06-3.15$ apfu and $\mathrm{X}_{\mathrm{Mg}}=$ 0.52-0.58; Fig. 5d), 2-3\% and ilmenite (14 mol. \% of pyrophanite).

\subsubsection{Granite porphyry}

Several dykes of granite porphyry (Fig. 3f) were exposed in the area Dood Ulaan Govi, east of the Munhkhairkhan soum. Dykes cut discordantly Devonian granite and sediments of the Tsetseg and Sagsai formations. Dykes strike $\mathrm{N}-\mathrm{S}$ to NNE-SSW, have thickness $5-10 \mathrm{~m}$ and length of $0.7-2.0 \mathrm{~km}$. The rock is massive, irregularly jointed and hard. Macroscopically it is expressively porphyritic rock with prominent isometric phenocrysts of quartz $(\sim 20$ 

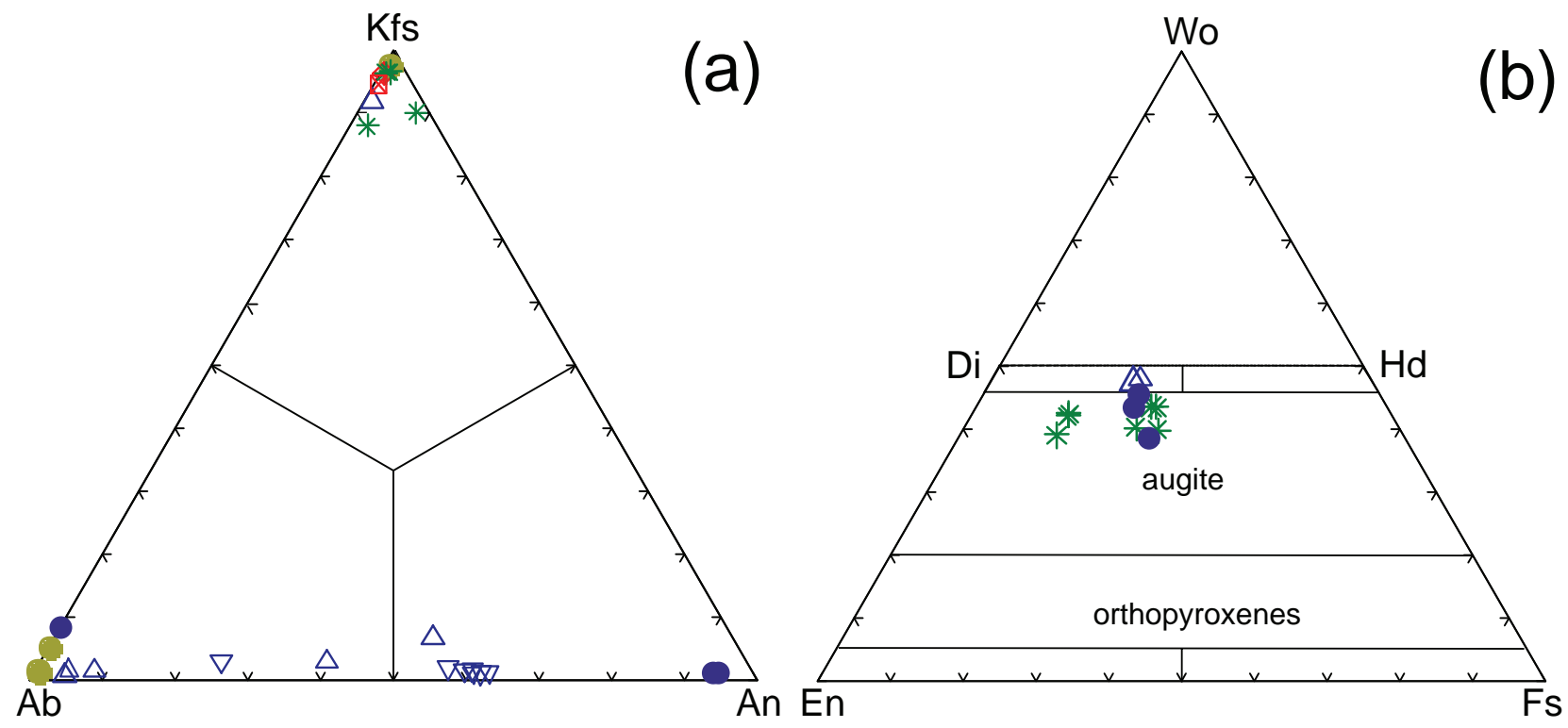

$A b$

An En

FS

(c)

(d)
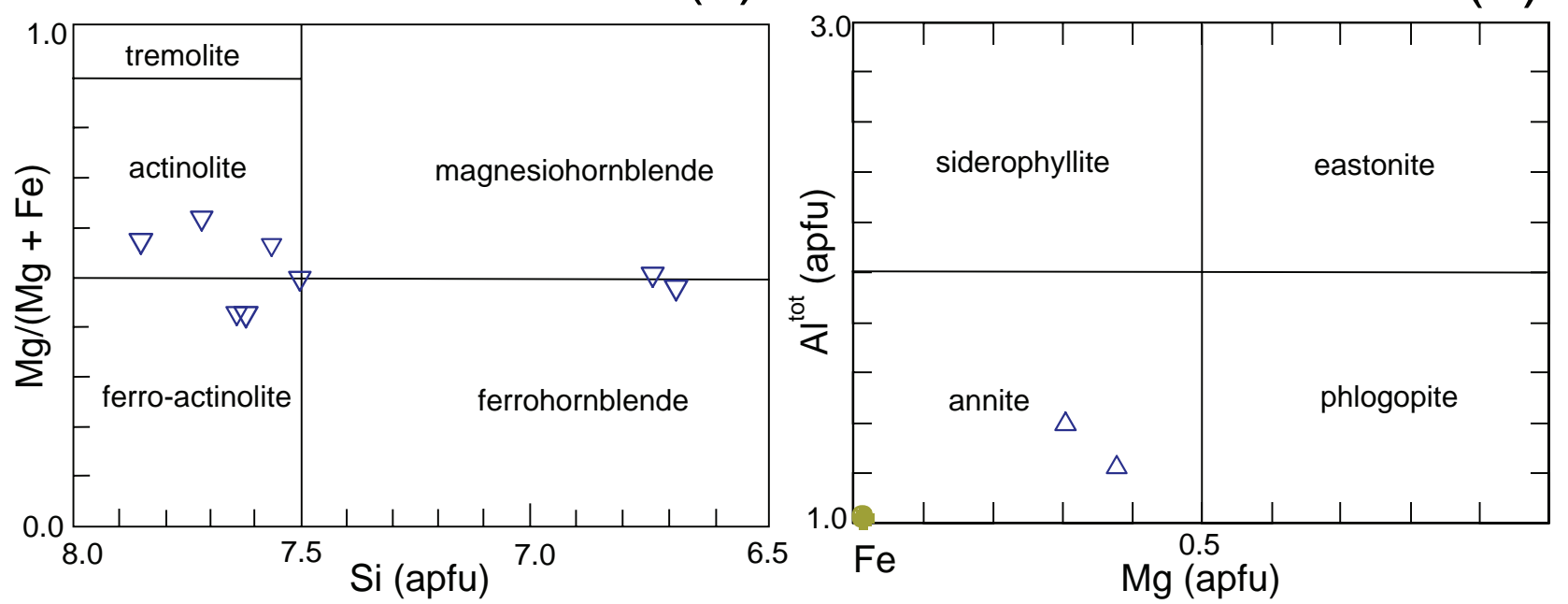

(e)
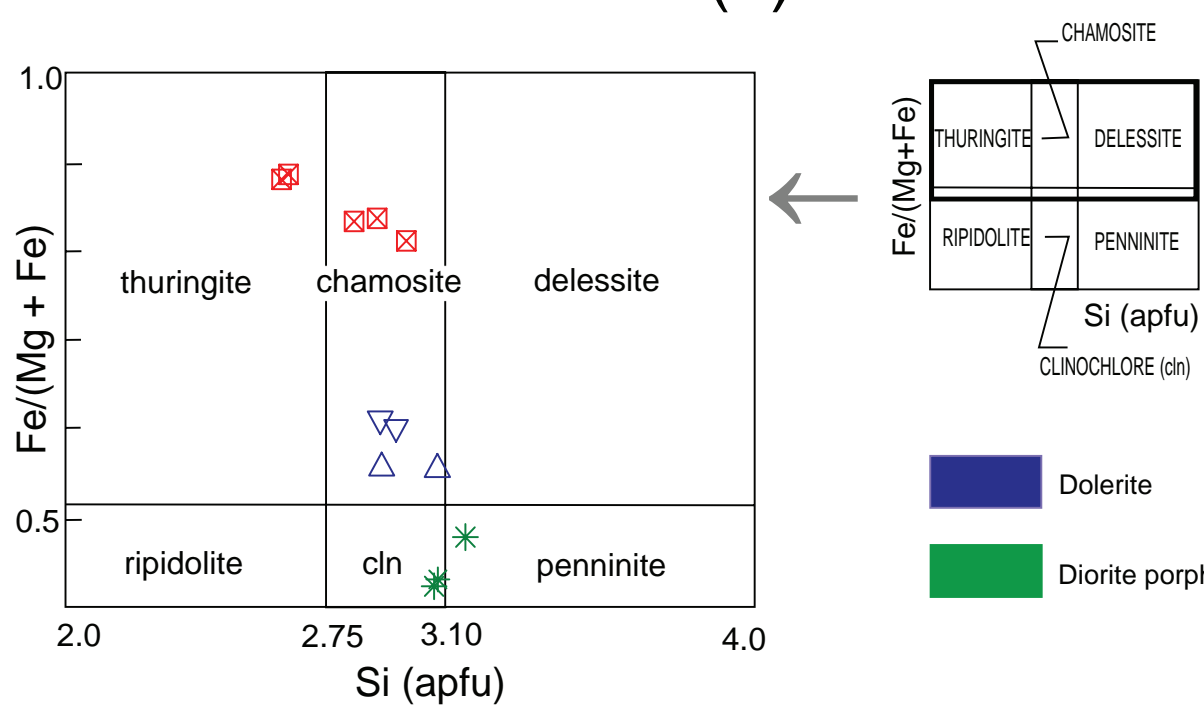

$-\mathrm{GC300b}$
$\triangle \mathrm{GZ053a}$
$* \mathrm{GZ095A}$
$\otimes \mathrm{GZ101}$
$-\mathrm{GZ195}$
$\nabla \mathrm{GZ298A} / 1$
$\star \mathrm{GZ318}$

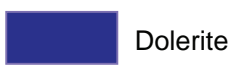

Granite porphyry

Diorite porphyry

Alkali rhyolite 
vol. \%), whitish plagioclase and pink K-feldspar (both together $\sim 25$ vol. \%), up to $7 \mathrm{~mm}$ across (Fig. 3f). There are also $\sim 2$ vol. $\%$ of white mica in the sample GZ318 (Fig. 4d): $\mathrm{Si}=3.26-3.36 \mathrm{apfu}, \mathrm{Al}=2.28-2.52 \mathrm{apfu}, \mathrm{Fe}=$ 0.21-0.29 apfu, $\mathrm{F}=0.05-0.09 \mathrm{apfu}$ ) occurring as euhedral tablets of size up to $2 \mathrm{~mm}$. Mica is sometimes slightly chloritized. Groundmass is very fine-grained, it has chocolate brown colour and it represents chilled glass (Fig. 3d). Part of groundmass is recrystallized in radiating spherulites of quartz and feldspars; the rest is extremely fine-grained equigranular mosaic of quartz and feldspars (Fig. 4e), rich in tiny subhedral to euhedral inclusions of ilmenite and hematite. Secondary chlorite is highly ferroan thuringite to chamosite ( $\mathrm{Si}=2.66-2.96$ apfu, $\mathrm{X}_{\mathrm{Mg}}=0.12-0.18$; Fig. 5e). Rutile and apatite are common accessory minerals.

\subsubsection{Alkali rhyolite}

Dykes of alkali rhyolite (Fig. 3h) crop out together with prevailing dykes of dolerite exclusively in the Botgon area (Fig. 2b). There are two dykes of thickness $2-5 \mathrm{~m}$ and several smaller ones $c .50 \mathrm{~cm}$ thick. The rock is grey massive, very hard, with rare macroscopically visible idiomorphic phenocrysts of quartz $(\sim 5$ vol. $\%)$, and of perthitic K-feldspar $(\sim 3$ vol. \%) up to size of $3 \mathrm{~mm}$ (Fig. 3h). Groundmass ( $\sim 80$ vol. \%) is composed of dominating very fine-grained mosaic of granophyric intergrowths of quartz and alkali feldspar that represent recrystallised glass (Fig. 4f). Accessory minerals (0.5-3 vol. \%) are annite, alkali amphibole and astrophyllite (Žáček et al. 2016). Alkali amphibole (riebeckite-arfvedsonite) has elevated content of $\mathrm{ZrO}_{2}$ up to $1.94 \mathrm{wt}$. \% and forms strongly pleochroic blue short- and long-prismatic crystals $0.01-0.2 \mathrm{~mm}$ long. Brown slightly pleochroic Fe-dominant astrophyllite occurs as radiating aggregates of up to $0.3 \mathrm{~mm}$ long and forms two generations: $\mathrm{Zr}-\mathrm{Nb}$ rich astrophyllite I and Zr-poor astrophyllite II. Both generations share an expressive dominance of $\mathrm{Fe}$ over $\mathrm{Mn}$, from the literature up till now unknown (see Žáček et al. 2016 and compare Piilonen et al. 2003). Accessories are zircon, ilmenite, hematite, monazite, and REE-rich fluorite; probable chevkinite and bastnäsite.

\subsection{Whole-rock geochemistry}

Based on the petrography two major groups can be distinguished: (1) felsic rocks (alkali rhyolite and granite porphyry) and (2) mafic rocks (dolerite, diorite porphyry).

«

Fig. 5 Chemical compositions of feldspars (a); clinopyroxenes (b); amphiboles (c), dark mica (d) and chlorites (e). The clinopyroxene classification diagram in (b) is after Morimoto (1988), diagram (c) follows Leake et al. (1997) for calcic amphiboles. For mineral chemistry see Electronic Supplementary Material.
The felsic rocks, according to their major-element composition, correspond to high-K calc-alkaline and, less commonly, shoshonitic (Fig. 6a-b; $\mathrm{SiO}_{2}=73-77$ wt. \%; $\mathrm{K}_{2} \mathrm{O}=4.3-7.2$ wt. $\%$ ), with variably low $\mathrm{Mg} \#[100 \times \mathrm{MgO} /$ $(\mathrm{FeOt}+\mathrm{MgO})(\mathrm{mol} . \%)]$ of 0.3-4.7. Based on immobile elements, two samples (GZ330, GZ195) can be interpreted as alkaline rhyolites (Pearce 1996, Fig. 6c). These are subaluminous $\left\{\mathrm{A} / \mathrm{CNK}\right.$ [molar $\left.\mathrm{Al}_{2} \mathrm{O}_{3} /\left(\mathrm{CaO}+\mathrm{Na}_{2} \mathrm{O}+\mathrm{K}_{2} \mathrm{O}\right)\right]$ 0.95 and $0.97 ; \mathrm{A} / \mathrm{NK}\left[\right.$ molar $\left.\mathrm{Al}_{2} \mathrm{O}_{3} /\left(\mathrm{Na}_{2} \mathrm{O}+\mathrm{K}_{2} \mathrm{O}\right)\right] 0.98$ and $1.03\}$, they show elevated zircon saturation temperatures of 859 and $875^{\circ} \mathrm{C}$ (Watson and Harrison 1983) and $\mathrm{Nb} / \mathrm{U}$ ratios of 13 and 18 (Fig. 6d). The other felsic rocks are subaluminous to peraluminous $(\mathrm{A} / \mathrm{CNK}=1.02-1.15$; $\mathrm{A} / \mathrm{NK}=1.09-1.25)$ with lower zircon saturation temperatures of $790-813^{\circ} \mathrm{C}$ (Watson and Harrison 1983) and lower $\mathrm{Nb} / \mathrm{U}$ ratios of $2-4$ (Fig. 6d).

The total REE content for all felsic rocks ranges from 135 to $265 \mathrm{ppm}$ (Tab. 2). The chondrite-normalised REE patterns (Boynton 1984) are relatively flat in the HREE area, and fractionated in the LREE segment $\left(\mathrm{La}_{\mathrm{N}} / \mathrm{Sm}_{\mathrm{N}}\right.$ $=2-5$; Fig. 7a). The distinct negative Eu anomaly $(\mathrm{Eu} /$ $\mathrm{Eu}^{*}=0.31-0.03 ;$ Tab. 2) and M-type tetrad effect $\left(\mathrm{TE}_{1-3}\right.$ $=1.04-1.14-$ the degree of the lanthanide tetrad effect sensu Irber 1999) are characteristic. Primitive Mantlenormalised trace-element patterns (McDonough and Sun 1995) display variable fractionation with negative anomalies of Sr, P, Eu, and HFSE (high-field-strength elements, Fig. 7b), and spikes of $\mathrm{Pb}$. The relatively high $\mathrm{K}_{2} \mathrm{O} / \mathrm{MgO}$ $(17-443), 10,000 \times \mathrm{Ga} / \mathrm{Al}$ (Fig. $8 \mathrm{a}-\mathrm{b})$ and $\mathrm{FeO} / \mathrm{MgO}$ (Fig. 8b) ratios indicate an A-type affinity (Whalen et al. 1987). Most of the samples fall within the field of $\mathrm{A}_{2}$-type granites in the $\mathrm{Nb}-\mathrm{Y}-3 \times$ Ga diagram (Eby 1992; Fig. 8c).

The mafic rocks correspond to alkaline or subalkaline basalts, basaltic trachyandesite, basaltic andesite, trachyandesite and andesite (Fig. 6a) $\left(\mathrm{SiO}_{2}=44-52\right.$ wt. \%; $\mathrm{K}_{2} \mathrm{O}$ $+\mathrm{Na}_{2} \mathrm{O}=2.8-5.7$ wt. \%; without normalisation to $100 \%$ on a volatile-free basis). Their major-element composition is transitional between calc-alkaline and alkaline basalts (Fig. $6 \mathrm{a}-\mathrm{b}$ ); however, the observed $\mathrm{Nb} / \mathrm{Y}$ ratios between 0.24 and 0.67 are typical of subalkaline basalts (Fig. 6c). The studied rocks also have low Mg\# values (18.4-30.0), $\mathrm{TiO}_{2}\left(1.7-3.2\right.$ wt. \%) and $\mathrm{K}_{2} \mathrm{O}(0.4$ to 3.2 wt. \%) contents (Tab. 2). In the binary variation diagrams (Fig. 9), they exhibit negative correlations of $\mathrm{SiO}_{2}$ with $\mathrm{MgO}, \mathrm{CaO}, \mathrm{TiO}_{2}$, $\mathrm{P}_{2} \mathrm{O}_{5}$ and positive ones with $\mathrm{Na}_{2} \mathrm{O}, \mathrm{Al}_{2} \mathrm{O}_{3}, \mathrm{~K}_{2} \mathrm{O}$, and Th contents, generally flat REE patterns (Boynton 1984; Fig. 7c) with slight enrichment in LREE and an indistinct, if any, Eu anomaly $\left(\mathrm{La}_{\mathrm{N}} / \mathrm{Yb}_{\mathrm{N}}=2.6-4.9 ; \mathrm{Eu} / \mathrm{Eu}^{*}=0.8-1.0 ; \mathrm{Tab} .2\right)$. The diorite porphyries also have flat chondrite-normalised REE patterns but with more fractionated LREE $\left(\mathrm{La}_{\mathrm{N}} / \mathrm{Yb}_{\mathrm{N}}=\right.$ 5.3 and $6.8 ; \mathrm{Eu} \mathrm{Eu}^{*}=0.8$ and $0.9 ; \mathrm{Tab}$. 2). In comparison to the Primitive Mantle (McDonough and Sun 1995), the diorite porphyries exhibit subparallel patterns with troughs for $\mathrm{Nb}, \mathrm{P}$ and $\mathrm{Ti}$ and spikes in lithophile elements (e.g. Cs, 

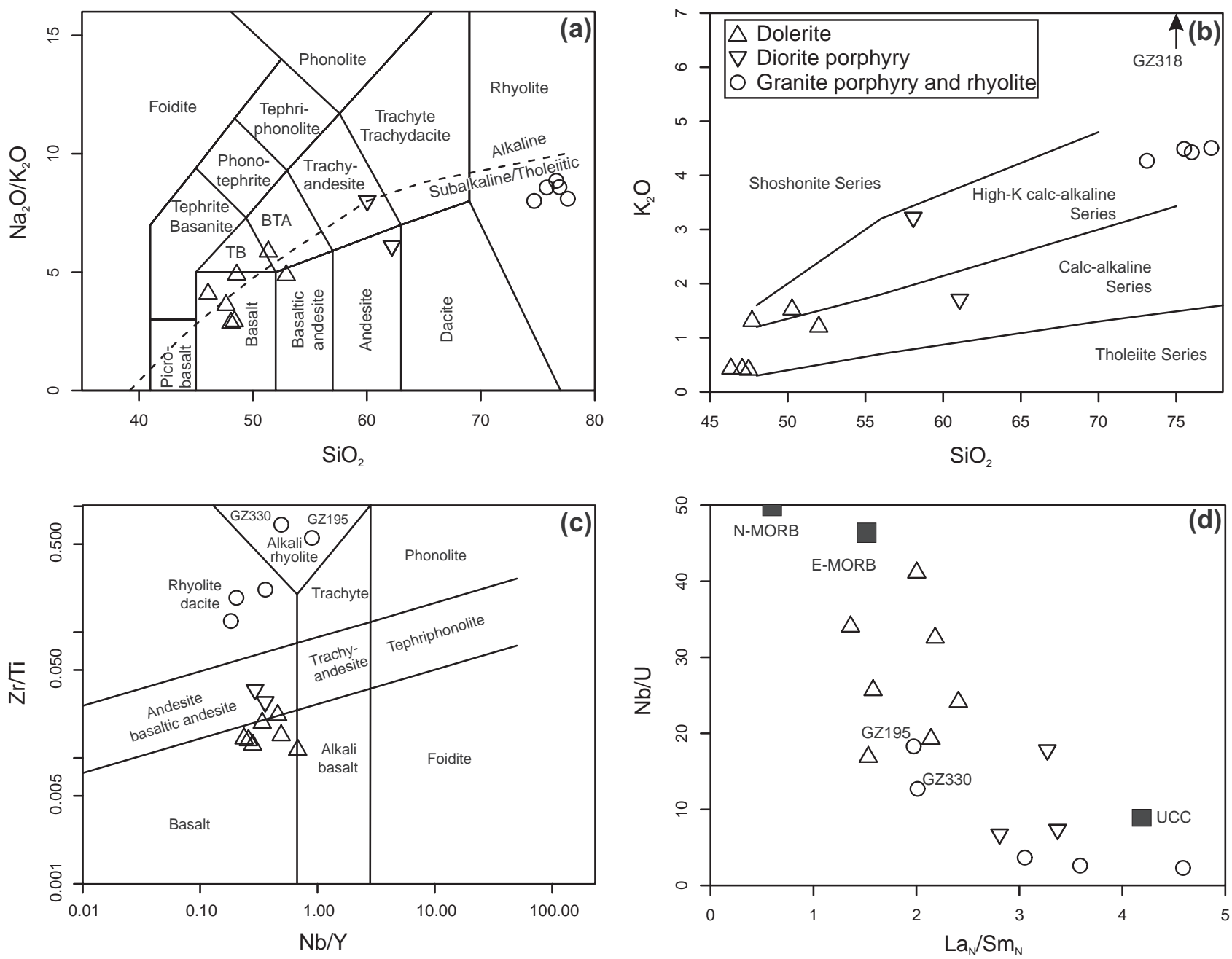

Fig. 6 Whole-rock geochemical discrimination diagrams. a - TAS (Total Alkalis vs. Silica) diagram after Le Bas et al. (1986). TB - trachybasalt, BTA - basaltic trachyandesite. b - $\mathrm{SiO}_{2}$ vs. $\mathrm{K}_{2} \mathrm{O}$ diagram after Peccerillo and Taylor (1976). c - Nb/Y vs. Zr/Ti diagram $(\mathrm{Pearce} 1996)$. d - La $/ \mathrm{Sm}{ }_{\mathrm{N}}$ vs. Nb/U diagram. Data sources: N-MORB and E-MORB: Sun and McDonough (1989), Upper Continental Crust (UCC): Taylor and McLennan (1995).

$\mathrm{Rb}$ and $\mathrm{Pb}$ ). Other basic rocks show variable enrichment in LILE (large-ion lithophile elements, Fig. 7d). Typical are relatively wide ranges in the content of $\mathrm{Zr}$ (112-422 ppm; Fig. 8d), Nb (6-83 ppm), Ce (54-94 ppm), and Y (34-109 $\mathrm{ppm})$. In the geotectonic $\mathrm{Zr}$ vs. $\mathrm{Zr} / \mathrm{Y}$ diagram of Pearce and Norry (1979) the rocks fall in the field of intraplate basalts (Fig. 8d) and in the $\mathrm{Nb} / \mathrm{Yb}$ versus $\mathrm{TiO}_{2} / \mathrm{Yb}$ diagram of Pearce (2008) most of the basic and intermediate rocks plot into the E-MORB field (enriched mid-ocean-ridge basalt) with some overlap to the OIB (ocean-island basalt) domain (Fig. 8e).

\subsection{K-Ar dating}

Seven of the eight samples studied yielded whole-rock $\mathrm{K}-\mathrm{Ar}$ ages ranging between $281 \pm 9$ and $300 \pm 9 \mathrm{Ma}$, with analytical errors expressed as $1 \sigma$ (Tab. 3).

One dated dolerite sample (GZ085A/3) from the Munhkhairkhan West dyke (Fig. 2) swarm gave an age of
$293 \pm 11 \mathrm{Ma}$. The rock corresponds to basaltic andesite to basalt and contains $0.29-0.32$ wt. \% K bound in plagioclase and scarce potassium feldspar (Fig. 4b). The sample shows only a weak alteration, the age is thus considered to be close to the emplacement age.

Two samples (GZ095A, GZ318) from the Munhkhairkhan East (Fig. 2) dyke swarm were dated. A sample of diorite porphyry (GZ095A) yielded $281 \pm 9$ $\mathrm{Ma}$, and a sample of granite porphyry (GZ318) gave $288 \pm 9 \mathrm{Ma}$. As the samples are slightly altered, the ages obtained are considered as the "minimum age" but close to the real magmatic age.

Five samples from the Botgon dyke swarm were dated, three dolerites (GZ053, GZ298A/1, GZ298A/2) and two rhyolites (GZ195, GZ330). The dolerites dated contain $0.83-1.33$ wt. $\% \mathrm{~K}$ and yielded the following ages: sample GZ053 = 284 \pm 9 Ma, sample GZ298A/1 = $283 \pm 9$ $\mathrm{Ma}$ and sample GZ298A/2 = 282 $\pm 9 \mathrm{Ma}$. As the rocks are slightly to moderately altered, the age is interpreted as the 

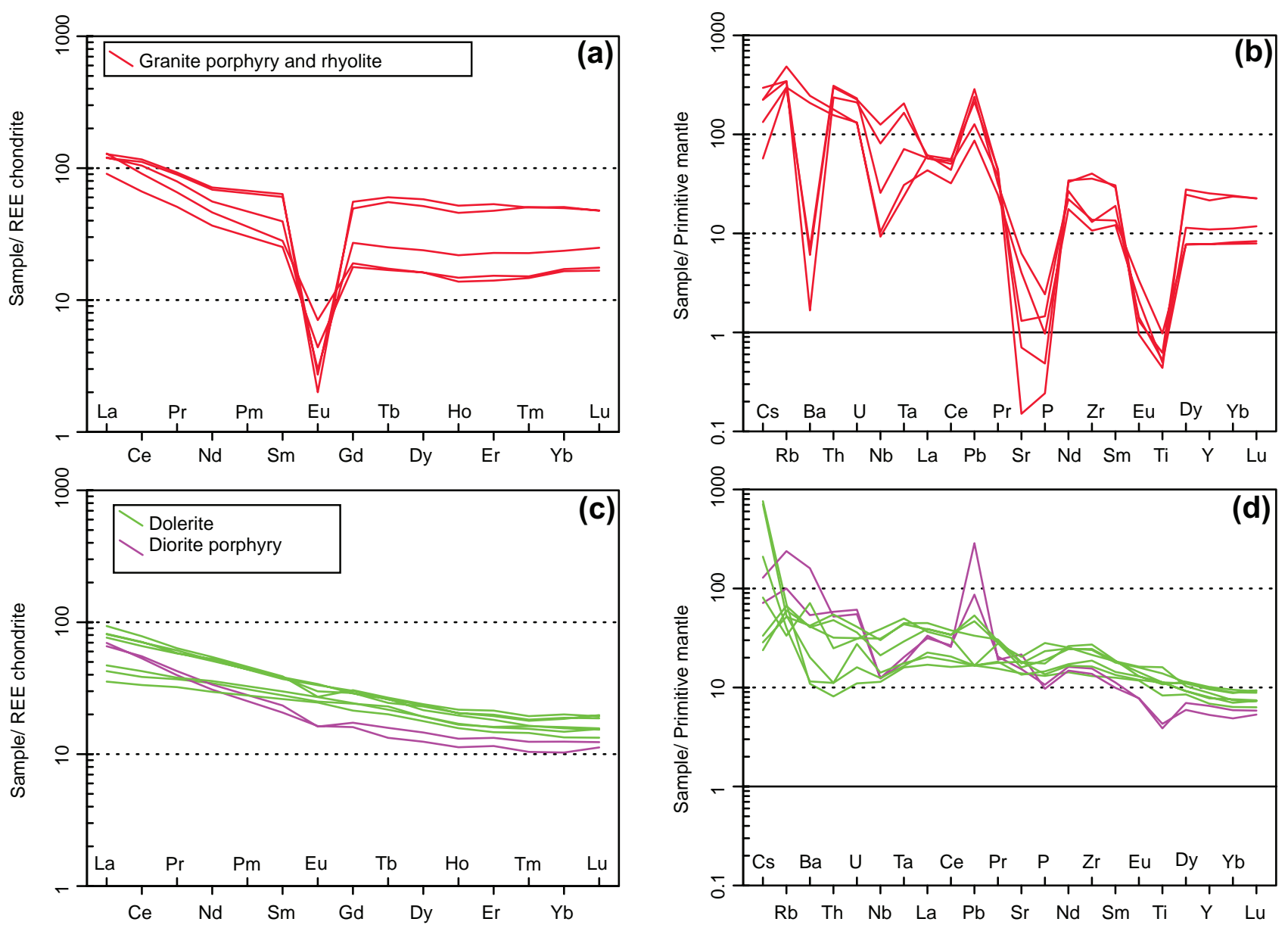

Fig. 7 Multi-element diagrams for felsic (a-b) and mafic (c-d) rocks: (a, c) Chondrite-normalised REE patterns and (b, d) Primitive Mantle-normalised patterns. Normalising values are taken from Boynton (1984) and McDonough and Sun (1995), respectively.

"minimum age" but likely close to the magmatic age. The alkali rhyolite GZ195, which contains 3.56 wt. \% K, was dated at $300 \pm 9 \mathrm{Ma}$ (Žáček et al. 2016). The potassium is bound mainly in potassium feldspar (Fig. 4f). As the dyke of rhyolite is unaltered and represents a small intrusive body, the $\mathrm{K}-\mathrm{Ar}$ age should be considered as the "age of emplacement". The other alkali rhyolite dyke (GZ330) was dated at $274 \pm 9 \mathrm{Ma}$. The rock is also unaltered but the sample was taken from the margin of the dyke. This age is, therefore, considered the "minimum age" due to possible disequilibria at the dyke margin.

Generally, all of the dated dykes belong to the same magmatic pulse. Early Permian or even latest Carboniferous ages (300-281 Ma) are considered as closely approaching the intrusive ages for all of the lithologies studied.

\section{Discussion}

\subsection{Effects of hydrothermal alteration}

Felsic rocks are mostly unaltered, characterised by relatively low loss on ignition (LOI 0.04-0.9 wt. \%), whereas some of the basic and intermediate samples show relatively high LOI (1.8 to 3.4 wt. \%). The weak alteration in the basic and intermediate rocks led to partial replacement of primary minerals and formation of secondary albite, calcite, pumpellyite, white mica, and chlorite. High activity of fluids during the closing phases of crystallization of dolerite and diorite dykes is evidenced by elevated concentrations of $\mathrm{Al}, \mathrm{Fe}$, and $\mathrm{F}$ in titanite $(0.16$ $\mathrm{Al}, 0.05-0.07 \mathrm{Fe}, 0.06-0.07 \mathrm{~F}$ apfu) and by the replacement of some primary phases by secondary minerals.

The effects of alteration are also visible from the varying abundance of LILE (esp. Cs, Rb and Ba: Fig. 7d) (Pearce and Cann 1973; Winchester and Floyd 1977). The alteration is interpreted as late magmatic or early post-magmatic and could lead to a slight lowering of the $\mathrm{K}-\mathrm{Ar}$ ages. The HFSE and REE can be considered immobile because they exhibit coherent normalised patterns for all of the studied samples and do not show significant correlations with the LOI.

The lanthanide tetrad effect observed in the rhyolites indicates a fluid/melt interaction within a felsic magmatic reservoir (Irber 1999). According to Yang et al. (2014), the formation of hydrothermal and metamict zircons can be responsible for the origin of the M-type tetrad effect. 

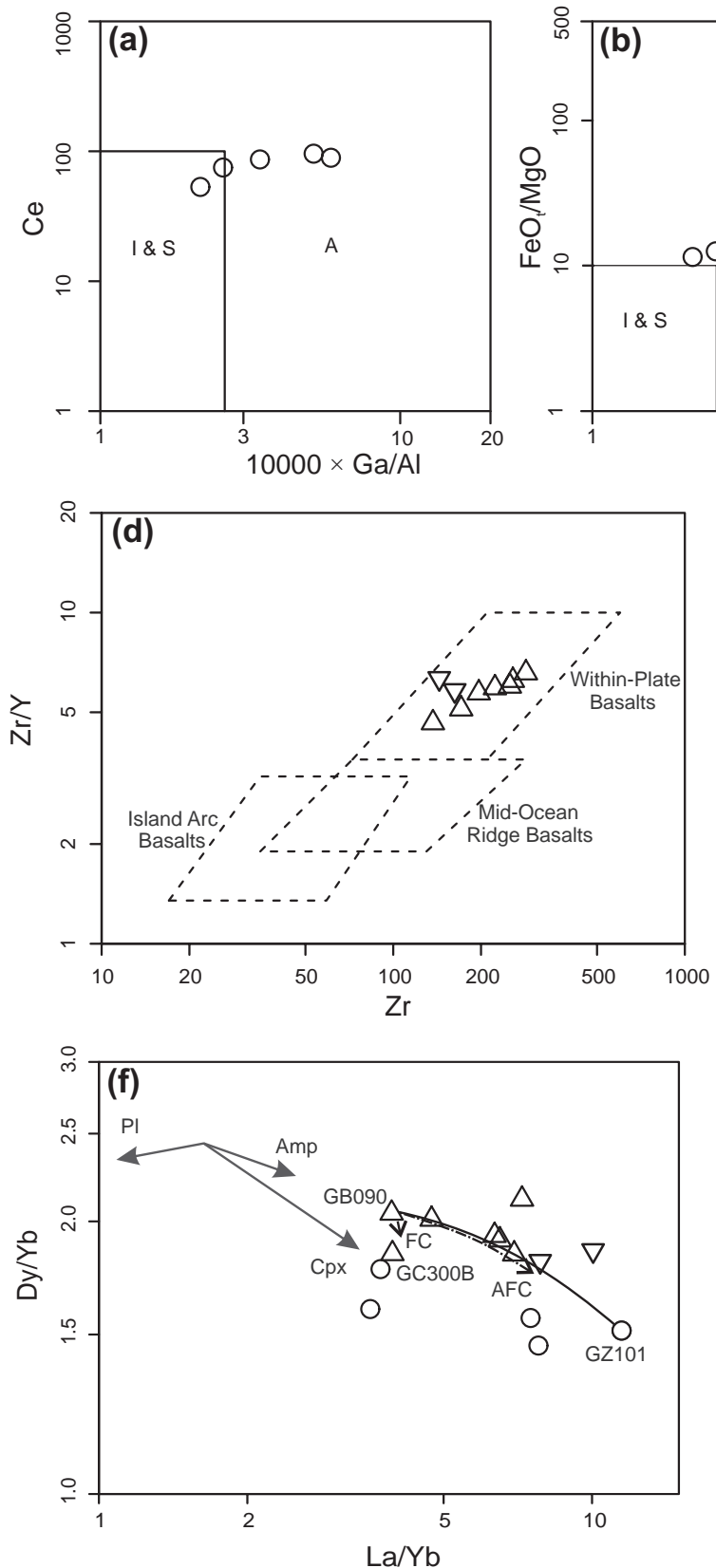
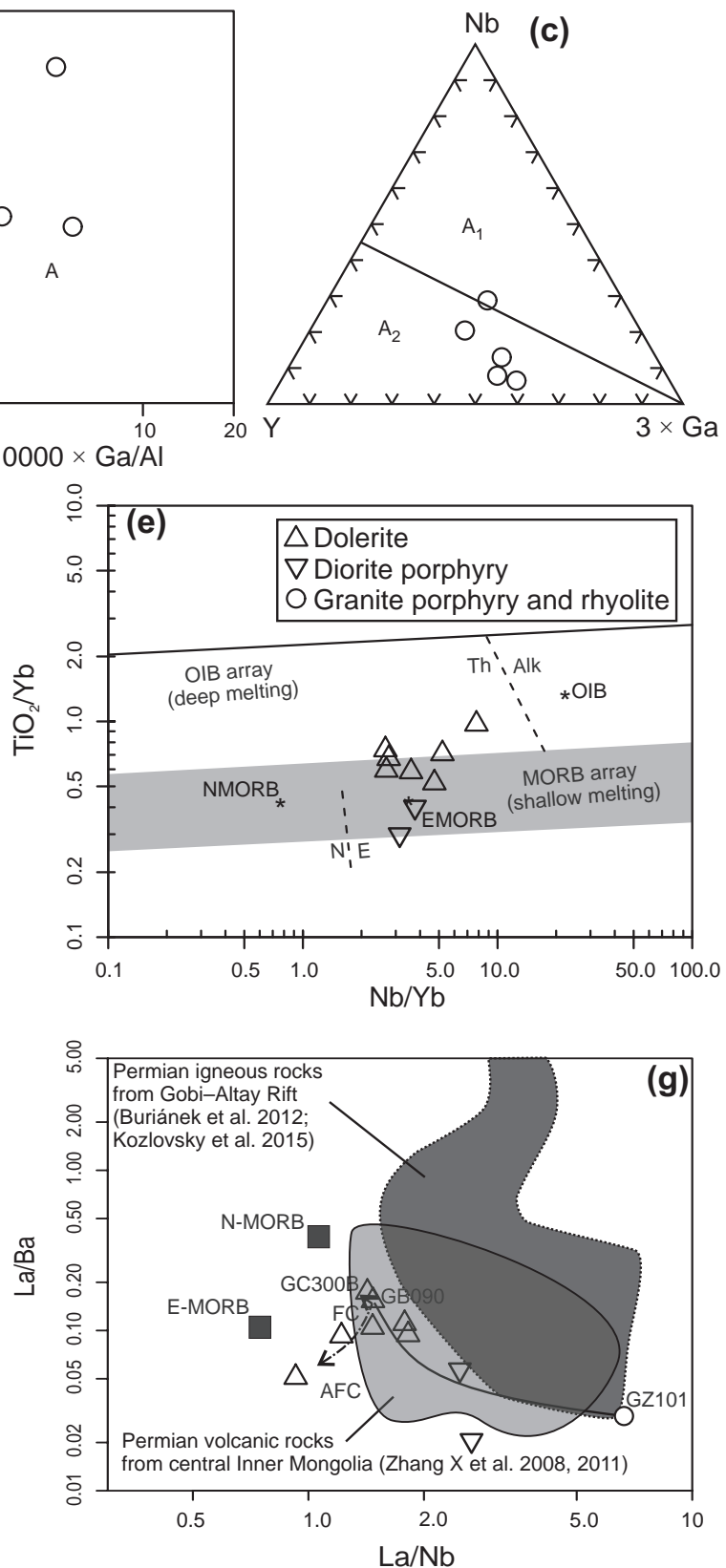

Fig. 8 Whole-rock geochemical diagrams. a -10,000 $\times$ Ga/Al vs. Ce (Whalen et al. 1987). b - 10,000× Ga/Al vs. FeOt/MgO (Whalen et al. 1987). Both diagrams show fields of I-, S-, and A-type granites. c - Ternary plot Y $-\mathrm{Nb}-3 \times$ Ga for classification of A-type granites (Eby 1992). d - Discrimination diagram Zr vs. Zr/Y (Pearce and Norry 1979). e - Nb/Y vs. TiO /Yb diagram (Pearce 2008). f - La/Yb vs. Dy/Yb plot showing theoretical Rayleigh fractionation vectors for up to $75 \%$ crystallization of amphibole, clinopyroxene and plagioclase in basalts (partition coefficients taken from McKenzie and O’Nions 1991). Geochemical modelling (FC-AFC-FCA modeler of Ersoy and Helvaci 2010) employed the partition coefficients for basic melt compositions. The starting composition used was sample GB090. The up to 45\% fractional crystallization trends for mafic rocks (FC and AFC models) are visible as dot and dash arrows (for detailed explanation, see the text). The solid line indicates binary mixing between the basaltic end-member (sample GB090) and the rhyolite (sample GZ101); g - La/Nb vs. La/Ba diagram for the basalts. N-MORB and E-MORB compositions are after Sun and McDonough (1989).

\subsection{The range of melting, crystallization and emplacement $P-T$ conditions}

The granite porphyries are characterised by low ratios $\mathrm{CaO} / \mathrm{Na}_{2} \mathrm{O}(0.06-0.38)$ and variable $\mathrm{Rb} / \mathrm{Ba}(0.1-3.7)$ and $\mathrm{Rb} / \mathrm{Sr}$ (1.4-6.8), which indicate a metaigneous or metapsammitic than rather metapelite source (e.g., Sylvester 1989; Jung and Pfänder 2007). The temperatures $\mathrm{T}_{\mathrm{Al} / \mathrm{Ti}}$ were calculated using an equation for metaigneous rock melting $\left(\mathrm{T}_{\mathrm{A} / \mathrm{Ti}}\left({ }^{\circ} \mathrm{C}\right)=\left[\ln (23,400)-\ln \left(\mathrm{Al}_{2} \mathrm{O}_{3} / \mathrm{TiO}_{2}\right)\right] /\right.$ 0.00729; Jung and Pfänder 2007). These $\mathrm{T}_{\mathrm{Al} / \mathrm{Ti}}$ values for the alkaline rhyolites and granite porphyries are similar, 

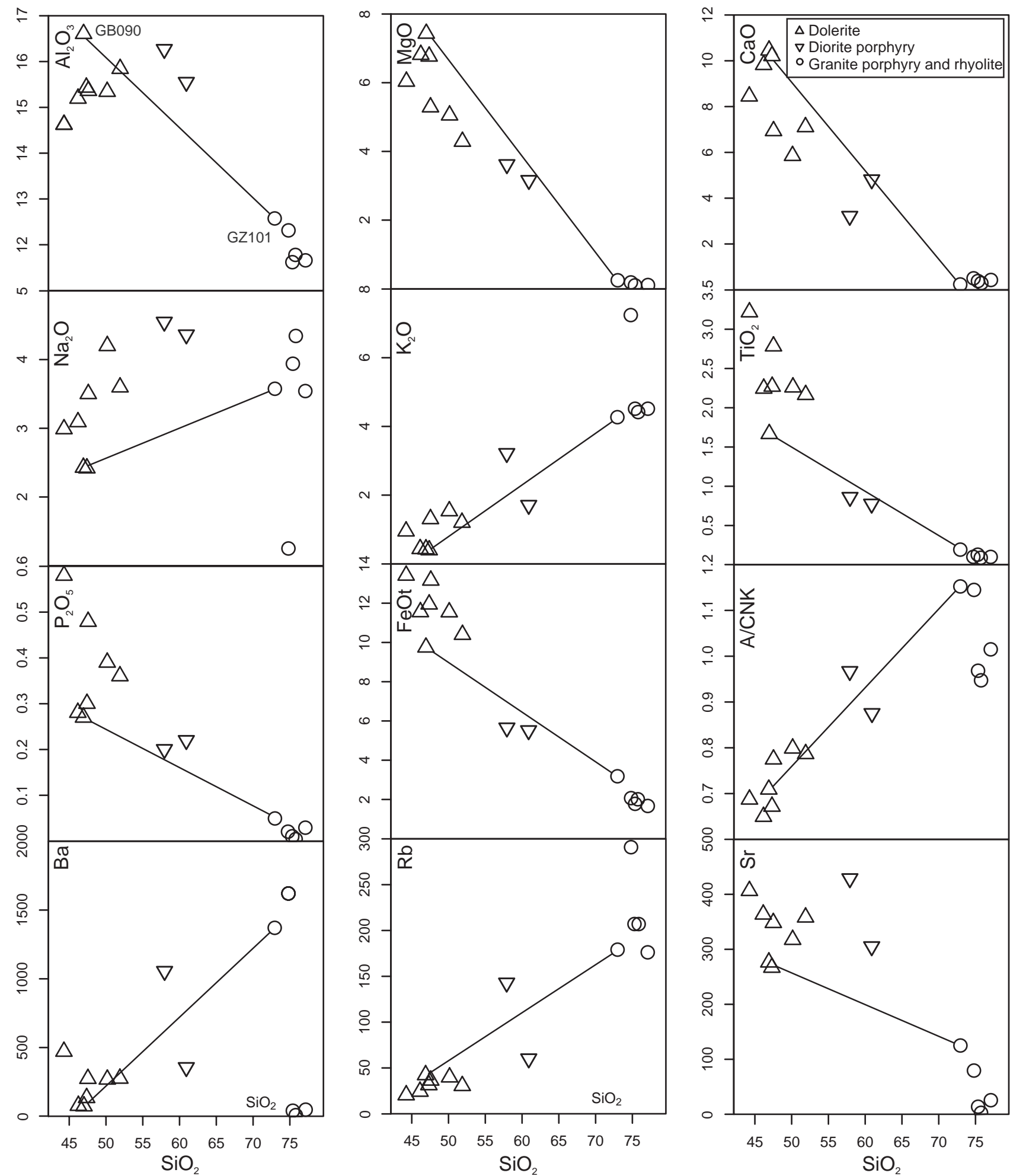

Fig. 9 Variation diagrams of silica versus selected major or trace elements. The solid grey line indicates mixing between the basaltic end-member (sample GB090) and the rhyolite (sample GZ101).

i.e. 708 and $758^{\circ} \mathrm{C}$ (samples GZ330 and GZ195) and $720-809^{\circ} \mathrm{C}$, respectively (Fig. 10a).

The alkaline rhyolites studied yielded zircon saturation temperatures $\left(\mathrm{T}_{\mathrm{Zr}}\right)$ of $859-875^{\circ} \mathrm{C}$. High $\mathrm{T}_{\mathrm{Zr}}\left(\sim 900^{\circ} \mathrm{C}\right)$ are typical of A-type granites (e.g. Clemens et al. 1986). The granite porphyries show lower $\mathrm{T}_{\mathrm{Zr}}$ of $790-813^{\circ} \mathrm{C}$ (Fig. 10a), which correspond to normal calc-alkaline felsic rocks (e.g. Schmidt and Thompson 1996). 

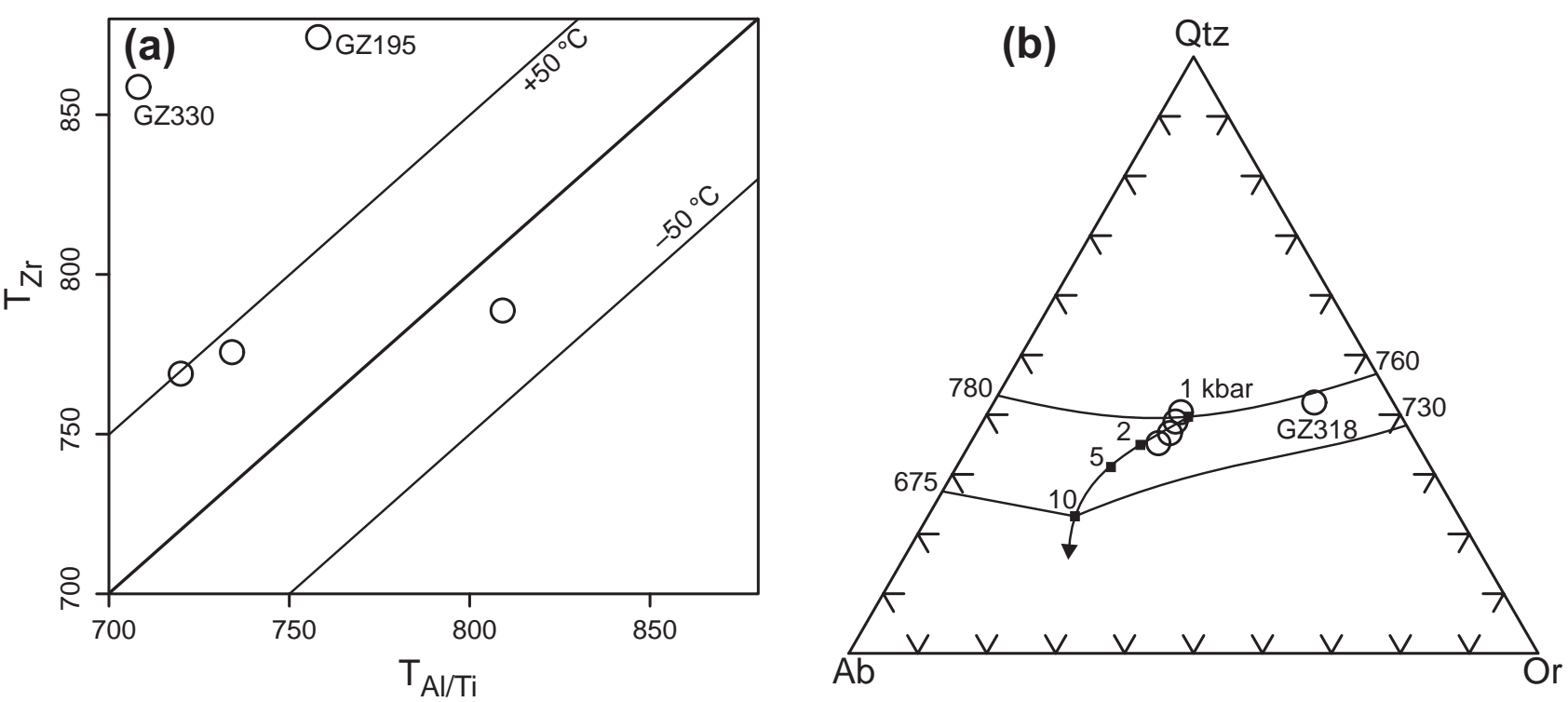

Fig. 10a Calculated temperatures $\left({ }^{\circ} \mathrm{C}\right)$ from zircon saturation thermometry $\left(\mathrm{T}_{\mathrm{Z}}\right.$ : Watson and Harrison 1983$)$ and $\mathrm{Al}-\mathrm{Ti}$ thermometry $\left(\mathrm{T}_{\mathrm{Al}-\mathrm{T}}:\right.$ exponential equation for metaigneous rocks, Jung and Pfänder 2007). b - CIPW-normative Ab-Qtz-Or triangle for felsic rocks (granite porphyry and rhyolite), lines and black squares are respectively cotectic lines and eutectic minima at 1, 2, 5 and 10 kbar for granitic melt under $\mathrm{H}_{2} \mathrm{O}$-saturated conditions (Johannes and Holtz 1996).

Chemical composition of the rhyolite can be used as an indicator for the emplacement depth of the dykes, because there exists correlation between the crystallization pressures of rhyolite melt and CIPW-normative composition during its solidification (e.g. Johannes and Holtz 1996 and the references therein). In the CIPW-normative $\mathrm{Ab}-\mathrm{Qtz}-\mathrm{Or}$ triangle, the studied rhyolites group between the 1 and 2 kbar water-saturated minima (Fig. 10b), likely reflecting their low level of emplacement in the crust. The position of the sample GZ318 (Fig. 10b) on the cotectic line depends on the conditions of crystallization and also composition of melt (e.g. $\mathrm{aH}_{2} \mathrm{O}<1$ ). Experimental data on the granite system also imply that increasing $\mathrm{CO}_{2}$ activity drives the minimum melt composition towards the orthoclase apex (Ebadi and Johannes 1991). We also used the empirical amphibole geothermobarometer of Ridolfi et al. (2010) to estimate the P-T conditions of crystallization for dolerite GZ298A. The results indicate temperatures from 713 to $735^{\circ} \mathrm{C}$. These low temperatures probably indicate subsequent subsolidus recrystallization due to interaction with fluids. The pressures range from 0.3 to $0.4 \mathrm{kbar}$ ( $\pm 0.03 \mathrm{kbar}$ for the lowest pressures and $\pm 0.05 \mathrm{kbar}$ for the highest pressures).

\subsection{Magmatic evolution of mafic rocks}

The mafic rocks in the variation diagrams exhibit a relatively wide range of $\mathrm{SiO}_{2}$ (44-61 wt. \%); however, often without clear correlation with other major and trace elements. Negative correlations of $\mathrm{SiO}_{2}$ with $\mathrm{MgO}, \mathrm{CaO}$, $\mathrm{TiO}_{2}$ and $\mathrm{FeO}_{\mathrm{t}}$ (Fig. 9) can be explained by the dominant fractionation a plagioclase and/or ferromagnesian phase (clinopyroxene, orthopyroxene and/or amphibole) together with Ti-rich minerals. In the variation diagrams, the effects of clinopyroxene fractionation are broadly similar to those of amphibole (e.g., Fig. 8f), but for a given composition $\mathrm{Kd}_{\mathrm{REE}}$ clinopyroxene and lower than those for amphibole (Davidson et al. 2007). Dolerites with amphiboles are slightly enriched in REE (157-171 $\mathrm{ppm}$ ) in comparison to clinopyroxene-dominated diorite porphyry $(87-158 \mathrm{ppm})$. The $\mathrm{La} / \mathrm{Yb}$ vs. Dy/Yb variation in mafic rocks indicates the predominance of clinopyroxene and/or amphibole fractionation (Fig. 8f). On the other hand, the modal composition of the fine-grained matrix (predominance of plagioclase and clinopyroxene over small contents of amphibole and orthopyroxene) indicates great importance of plagioclase and clinopyroxene during fractional crystallization of the mafic rocks.

Pure fractional crystallization (FC) of plagioclase and clinopyroxene would be able to explain the behaviour of oxides (e.g. $\mathrm{CaO}$ and $\mathrm{Al}_{2} \mathrm{O}_{3}$ ), but not the changes in $\mathrm{K}_{2} \mathrm{O}$ and some LIL, HFS elements in majority of dolerite samples (except sample GC300B; Fig. 9f-g). Wide variations in $\mathrm{K}_{2} \mathrm{O}(0.3-3.2$ wt. \%) and $\mathrm{Th}(0.7-4.7 \mathrm{ppm})$ can indicate that crustal contamination played a significant role during the generation of the mafic magmas (Fig. 8; 9f-g). Basaltic melts contaminated by crustal materials should be enriched in LREE and LILE, but depleted in $\mathrm{Nb}, \mathrm{Ta}$ and Ti (Rudnick and Gao 2004). According to the $\mathrm{La} / \mathrm{Nb}$ ratios (index of crustal contamination, Kieffer et al. 2004), the majority of the basic rocks are contaminated with the continental crust $(\mathrm{La} / \mathrm{Nb}=0.9-1.8)$.

Diorite porphyry samples have elevated $\mathrm{K}, \mathrm{Cs}, \mathrm{Rb}$, $\mathrm{Pb}$ and lower $\mathrm{Nb}, \mathrm{Ta}, \mathrm{P}, \mathrm{Ti}$, and HREE contents (Tab. 2). 
In comparison to the studied dolerites, they have more fractionated REE patterns, higher $\mathrm{Th} / \mathrm{Ce}(\sim 0.1$ vs. $0.02-$ $0.07), \mathrm{Th} / \mathrm{La}(0.19-0.23$ vs. $0.06-0.15)$ and lower $\mathrm{Nb} / \mathrm{U}$ ( $\sim$ vs. 31-34) ratios. In addition, the presence of mafic microgranular enclaves and disequilibrium textures (e.g., resorption of plagioclase, quartz xenocrysts surrounded by amphiboles - ocellar quartz) in the diorite porphyry could be considered consistent with mixing and mingling processes between felsic crustal and mafic mantle-derived melts (e.g., Vernon 1991; Janoušek et al. 2000; Castro 2001).

Proportion of fractionating mineral phases for the FC modelling was chosen according to average modal composition of dolerite matrix as well as relatively stable ratio between clinopyroxene and plagioclase in the mineral assemblage of the studied samples (e.g. for the sample GC300B: plagioclase $=40$ vol. $\%$, clinopyroxene 35 vol. $\%$ and other minerals 25 vol. \%). The dolerite sample GC300B (Fig. 8f-g) plots close to this fractionation trend; however majority of dolerite samples show lower $\mathrm{La} / \mathrm{Ba}$ ratios (Fig. 8g), which can been considered as a result of assimilation of crustal material by the mafic melt during its ascent or of magma mixing and mingling with a crustal melt.

Therefore, we modelled mixing of mafic magmas with crustal materials derived from outside the magma chamber, simultaneously with fractional crystallization (the process of Assimilation and Fractional Crystallization; AFC - DePaolo 1981). We used the rate of assimilation to fractional crystallization (r) of 0.5 and average composition of the upper continental crust (Taylor and McLennan 1995) as an assimilant. The chemical variation of dolerites can be modelled by removing less than $36 \mathrm{wt}$. $\%$ of plagioclase and ferromagnesian minerals (mainly clinopyroxene, Fig. $8 \mathrm{f}-\mathrm{g}$ ). We used the same parameters as for FC, including the $\mathrm{Kd}$ values, proportions of minerals in the cumulate and $45 \%$ crystallization; hypothetical parental magma composition was taken from the least fractionated dolerite sample GB090.

Simple magma mixing trend (Figs $8 \mathrm{f}-\mathrm{g}$; 9) for basic and intermediate rocks was calculated using chemical compositions of dolerite (GB090) and rhyolite (GZ101) and can explain much of the observed variability of the diorite porphyry samples and some of the dolerites. This is also supported by the position of the diorite porphyries on the linear trends between rhyolites and basalts on some variation diagrams (Fig. 9) as well as position in the $\mathrm{La} / \mathrm{Nb}$ vs. $\mathrm{La} / \mathrm{Ba}$ diagram (Fig. $8 \mathrm{~g}$ ).

Taken together, the mantle-derived melt was probably modified by fractional crystallization (in particular plagioclase and clinopyroxene) simultaneously with assimilation of crustal rocks in the case of dolerites, while magma mixing with the crustal melt is the best genetic scenario for the diorite porphyries.

\subsection{Magmatic evolution of the felsic rocks}

Compositions of the studied felsic rocks pass from peraluminous to subaluminous, with a variable content of LILE, $\mathrm{Nb}$, Ta and $\mathrm{Zr}$ (Fig. 7b), typical of post-collisional and anorogenic suites (e.g. Whalen et al. 1987; Sylvester 1989; Barbarin 1999; Yuan et al. 2016). Such compositions could be generated by partial melting of the juvenile continental crust (e. g. Zheng et al. 2008). Enrichment in LILE and LREE as well as negative anomalies in HFSE (mainly $\mathrm{Nb}$ and Ta; Tab. 2) are common features inherited from pre-existing arc-derived magmatic or sedimentary rocks (Taylor and McLennan 1995).

Post-collisional melts can be generated through several different magmatic processes, including partial melting of crustal rocks, fractional crystallization of mantle-derived melts, with, or without, assimilation of crustal material and/or magma mixing between mantle-derived and crustal melts (Collins et al. 1982; Clemens et al. 1986; Whalen et al. 1987; Creaser et al. 1991; Eby 1992; Turner et al. 1992; King et al. 1997). Following the classification of A-type granites (Eby 1992; Frost and Frost 2011), the studied rhyolites and granite porphyries show features of $\mathrm{A}_{2}$-type granites suggesting partial melting of continental crust, except sample GZ195 which is situated in field $A_{1}$ (Žáček et al. 2016). The relatively variable $\mathrm{Nb} / \mathrm{Y}$ ratios can be interpreted as the result of interaction between crustal and mantle-derived melts (e.g. Eby 1992; Frost and Frost 2011). Relatively low Nb, Ta, Zr and REE contents compared to typical A-type granites may have resulted from crustal signature and/or alteration ( $\mathrm{Li}$ et al. 2014).

The variable negative $\mathrm{Sr}, \mathrm{P}, \mathrm{Eu}$ and Ti anomalies in the multielement plot (Fig. 7b) can be interpreted as a result of fractionation of feldspars, apatite and Ti-rich minerals. However, minor variations in the $\mathrm{SiO}_{2}$ contents suggest relatively small degrees of fractional crystallization.

\subsection{Geotectonic implications}

The geochemical signatures of the studied mafic rocks indicate typical intraplate continental settings (e. g. LREE/ HREE enrichment and high $\mathrm{Zr} / \mathrm{Y}$; Pearce and Norry 1979). Variably developed negative to weak positive $\mathrm{Nb}$ anomaly $\left((\mathrm{La} / \mathrm{Nb})_{\mathrm{PM}}=0.9-1.8\right)$ is typical of rift-related Late Palaeozoic basic and intermediate rocks from the southern Mongolia (e.g. Kozlovsky et al. 2006). High La/ $\mathrm{Nb}$ and low La/Ba (Fig. 8g) are comparable with compositions of Permian volcanic rocks from the central Inner Mongolia (Zhang X et al. 2008, 2011). A-type geochemical affinity of studied felsic rocks is also consistent with this tectonic scenario.

Late Carboniferous to Early Permian bimodal volcanic rocks and peralkaline granites (320-290 Ma) are wide- 
spread in western Mongolia (e.g. Yarmolyuk et al. 2005, 2013b, 2016; Shen et al. 2011; Kozlovsky et al. 2015). The Late Palaeozoic magmatic stage (younger than $~ 308$ $\mathrm{Ma}$ ) in the southern Altai Range was characterised by small intrusions of A-type felsic and mafic to ultramafic melts (Shen et al. 2011). Volcanic activity in the Northern Mongolian Rift was slightly younger (249-270 Ma; Yarmolyuk et al. 2005). The emplacement of A-type felsic and mafic volcanic rocks in the western Mongolian Altai at 281-300 Ma was contemporaneous with bimodal volcanic activity in the Gobi-Altai Rift (279-293 Ma; Buriánek et al 2012; Kozlovsky et al. 2015), volcanic activity in the Zhaheba Depression of East Junggar (276-317 Ma; Li et al. 2014) and bimodal magmatism in the Chinese Altai (256-291 Ma; Cai et al. 2015).

Late Carboniferous to Early Permian bimodal magmatism has commonly been ascribed to a continentalrift setting (Kovalenko VI et al. 2004; Yarmolyuk et al. 2008; Zhang X et al. 2008; Jahn et al. 2009; Buriánek et al 2012). This within-plate magmatic activity at the margin of Siberia was related to Late Palaeozoic-Early Mesozoic Central Asian rifting that was manifested in several rifts of different ages (e.g. Yarmolyuk et al. 2005, 2013b). According to Yarmolyuk et al. (2013b), the Late Palaeozoic rifting propagated progressively from the continent margin toward the interior, and, at the same time, the Palaeo-Asian ocean started to close (e.g. Liu Q et al. 2017). This rift-related magmatism is thought to have formed above a mantle hot spot, which could have existed previously in the PalaeoAsian Ocean (Yarmolyuk et al. 2013b). Positive Pb and negative $\mathrm{Nb}$ anomalies in the studied samples indicate that a significant role in the formation of basaltic melt during Late Palaeozoic rifting (Kozlovsky et al. 2006; Zhang CL et al. 2014) could have been played by the metasomatised mantle wedge, previously contaminated by subduction of the oceanic crust (McCulloch and Gamble 1991; Kelemen et al. 1993).

The Early Permian acid volcanic rocks from central Inner Mongolia (Zhang X et al. 2008, 2011) as well as granitoids (granites, monzogranites, syenogranites and peralkaline granites) in the Chinese Altai (Tong et al. 2014) show a chemical composition similar to the studied subvolcanic rocks (e. g. significant negative anomalies of $\mathrm{Nb}, \mathrm{Ba}, \mathrm{Sr}, \mathrm{P}$, and $\mathrm{Ti}$ in the Primitive Mantle-normalised diagram for the acid volcanic rocks). According to the geochemical, isotopic $\left(\varepsilon_{\mathrm{Nd}}(\mathrm{t})=+1.3\right.$ to +7.2$)$ and zircon $\varepsilon_{\mathrm{Hf}}(\mathrm{t})=+5.6$ to +12.9$)$ compositions, the granitoids in the Chinese Altai were interpreted as the products of differentiation of mantle-derived magmas with a variable amount of crustal contamination. They could have been related to asthenospheric upwelling following after the collision and amalgamation of the Altai (Kovalenko VI et al. 2004; Blight et al. 2010; Tong et al. 2014).

\section{Conclusions}

Swarms of felsic and mafic dykes in the western Mongolian Altai cut rocks of Ordovician to Early Carboniferous age. The position and geochemical composition of dyke swarms in the Hovd and Altai zones of the western Mongolian Altai are consistent with rift-related geodynamic setting. The mafic (basalt, basaltic andesite and diorite porphyry) and felsic (granite porphyry, alkaline rhyolite) dykes were emplaced at 281-300 $\pm 9-11(1 \sigma)$ Ma. Calculated pressure conditions for crystallization of 1-2 kbar and 0.3-0.4 kbar for felsic and mafic rocks, respectively, indicate emplacement at shallow crustal levels. This igneous activity was coeval with the Permian magmatism in the Gobi-Altai Rift and magmatism in the Chinese Altai (e.g. Eastern Kazakhstan Rift). The bimodal nature of the associations and the transitional calc-alkaline to alkaline character of the dykes indicate magma production through the partial melting of mantle and continental crust in a rift-related setting.

Acknowledgments. The field-work was supported by the Czech Development Agency project "Geological mapping 1:50,000 and assessment of economic potential of selected region in Western Mongolia" CzDA-ROMN-2013-1-32220. The article was supported by the Czech Geological Survey, Projects Nos 681800 and 321183. The authors are grateful to Pavel Čáp, Tomáš Vorel, Igor Soejono, Kryštof Verner, Bayart Nadmid and Soylo-Erdene Ulziisuren for valuable field assistance, to Stanislav Vrána for microscopic studies of rocks and to Vladislav Rapprich for his assistance in sample preparation for $\mathrm{K}-\mathrm{Ar}$ geochronology. The authors are also grateful to Jeremie Lehmann, Ochir Gerel and an anonymous reviewer for valuable comments, Pavlína Hasalová and Vojtěch Janoušek for careful handling and to the anonymous proof-reader for improvement of the English language.

Electronic supplementary material. Supplementary tables of chemical compositions with recalculated crystalformulae of feldspars, clinopyroxene, amphibole, biotite, muscovite, chlorite, epidote, prehnite, titanite, ilmenite, and rutile are available online at the Journal web site (http://dx.doi.org/10.3190/jgeosci.280).

\section{References}

Badarch G, Cunningham CW, Windley BF (2002) A new terrane subdivision for Mongolia: implications for the Phanerozoic crustal growth of Central Asia. J Asian Earth Sci 21: 87-110

BALOGH K (1985) K/Ar dating of Neogene volcanic activity in Hungary: experimental technique, experiences 
and methods of chronologic studies. ATOMKI Report D/1: 277-288

BARBARIN B (1999) A review of relationships between granitoid types, their origins and their geodynamic environments. Lithos 46: 605-626

Blight JHS, Crowley QG, Petterson MG, Cunningham D (2010) Granites of the southern Mongolia Carboniferous arc: new geochronological and geochemical constraints. Lithos 116: 35-52

BOYNTON WV (1984) Cosmochemistry of the rare earth elements: meteorite studies. In: HeNDERSON P (ed) Rare Earth Element Geochemistry. Elsevier, Amsterdam, pp 63-114

Buriánek D, HanžL P, Budil P, Gerdes A (2012) Evolution of the Early Permian volcanic-plutonic complex in the western part of the Permian Gobi-Altai Rift (Khar Argalant Mts., SW Mongolia). J Geosci 57: 105-126

Buslov MM, Safonova IY, Watanabe T, Obut OT, Fujiwara Y, Iwata K, Semakov NN, Sugai Y, Smirnova LV, KaZANSKY AY (2001) Evolution of the Paleo-Asian Ocean (Altai-Sayan Region, Central Asia) and collision of possible Gondwana-derived terranes with the southern marginal part of the Siberian Continent. Geosci J 5: 203-224

Cai K, Sun M, Jahn BM, Xiao WJ, Yuan C, Long X, Chen H, Tumurkhuu D (2015) A synthesis of zircon $\mathrm{U}-\mathrm{Pb}$ ages and $\mathrm{Hf}$ isotopic compositions of granitoids from southwest Mongolia: implications for crustal nature and tectonic evolution of the Altai Superterrane. Lithos 232: $131-142$

CASTRO A (2001) Plagioclase morphologies in assimilation experiments: implications for disequilibrium melting in the generation of granodiorite rocks. Mineral Petrol 71: 31-49

Chen B, Arakawa Y (2005) Elemental and Nd-Sr isotopic geochemistry of granitoids from the West Junggar foldbelt (NW China), with implications for Phanerozoic continental growth. Geochim Cosmochim Acta 69: $1307-1320$

Chen B, JAHN BM (2004) Genesis of post-collisional granitoids and basement nature of the Junggar Terrane, NW China: Nd-Sr isotopic and trace element evidence. J Asian Earth Sci 23: 691-703

Clemens JD, Holloway JR, White AJR (1986) Origin of an A-type granite: experimental constraints: Amer Miner 71: 317-324

Collins WJ, Beams SD, White AJR, Chappell BW (1982) Nature and origin of A-type granites with particular reference to southeastern Australia. Contrib Mineral Petrol 80: 189-200

Creaser RA, Price RC, Wormald RJ (1991) A-type granites revisited: assessment of a residual-source model. Geology 19: 163-166
Cox AV, Dalrymple GB (1967) Statistical analysis of geomagnetic reversal data and the precision of potassium-argon dating. J Geophys Res 72: 2603-2614

Davidson J, Turner S, Handley H, Macpherson C, Dosseto A (2007) Amphibole "sponge" in arc crust? Geology 35: 787-790

DePaolo DJ (1981) Trace element and isotopic effects of combined wall rock assimilation and fractional crystallization. Earth Planet Sci Lett 53: 189-202

Don J (1977) The geology of the Altai Mts, Mongolia, in the drainage basin of the Khoytu Tsenkher-Gol (river). Biul Inst geol 302: 165-290

Dumicz M (1977) The tectonics of the Altai Mts. in Mongolia and of the Great Lake Basin in the Kobdo region. Biul Inst geol 302: 5-163

Ebadi A, Johannes W (1991) Beginning of melting and composition of first melts in the system Qz-Ab-Or- $\mathrm{H}_{2} \mathrm{O}$ $\mathrm{CO}_{2}$. Contrib Mineral Petrol 106: 286-295

EBy GN (1992) Chemical subdivision of the A-type granitoids: petrogenetic and tectonic implications. Geology 20: 641-644

Ersoy Y, HelvaCi C (2010) FC-AFC-FCA and mixing modeler: a Microsoft ${ }^{\circledR}$ Excel $^{\odot}$ spreadsheet program for modeling geochemical differentiation of magma by crystal fractionation, crustal assimilation and mixing. Comput Geosci 36: 383-390

Frost CD, Frost BR (2011) On ferroan (A-type) granitoids: their compositional variability and modes of origin. J Petrol 52: 39-53

Gavrilova SP, Zaitsev NS, Pavlov VA, Yashina RM (1975) Granitoid and Alkaline Formations in Structures of Western and Northern Mongolia. Nauka, Moscow, pp 1-288 (in Russian)

IRBER W (1999) The lanthanide tetrad effect and its correlation with $\mathrm{K} / \mathrm{Rb}, \mathrm{Eu} / \mathrm{Eu}^{*}, \mathrm{Sr} / \mathrm{Eu}, \mathrm{Y} / \mathrm{Ho}$, and $\mathrm{Zr} / \mathrm{Hf}$ of evolving peraluminous granite suites. Geochim Cosmochim Acta 63: 489-508

JAHN BM (2004) The Central Asian Orogenic Belt and growth of the continental crust in the Phanerozoic. In: Malpas J, Fletcher CJN, Ali JR, Aitchison JC (eds) Aspects of the Tectonic Evolution of China. Geological Society of London Special Publications 226: 73-100

JAHN BM, Wu FY, CHEN B (2000) Granitoids of the Central Asian Orogenic Belt and continental growth in the Phanerozoic. Trans Roy Soc Edinb, Earth Sci 91: 181-193

Jahn BM, Litvinovsky BA, Zanvilevich AN, Reichow MK (2009) Peralkaline granitoid magmatism in the Mongolian-Transbaikalian Belt: evolution, petrogenesis and tectonic significance. Lithos 113: 521-539

Janoušek V, Bowes DR, Braithwaite CJR, Rogers G (2000) Microstructural and mineralogical evidence for limited involvement of magma mixing in the petrogenesis of a Hercynian high-K calc-alkaline intrusion: the Kozárovice granodiorite, Central Bohemian Pluton, 
Czech Republic. Trans Roy Soc Edinb, Earth Sci 91: $15-26$

JANOUŠEK V, FARROW CM, ERBAN V (2006) Interpretation of whole-rock geochemical data in igneous geochemistry: introducing Geochemical Data Toolkit (GCDkit). J Petrol 47: 1255-1259

Johannes W, Holtz F (1996) Petrogenesis and Experimental Petrology of Granitic Rocks. Springer, Berlin, pp 1-335

JUNG S, PFÄNDER JA (2007) Source composition and melting temperatures of orogenic granitoids: constraints from $\mathrm{CaO} / \mathrm{Na}_{2} \mathrm{O}, \mathrm{Al}_{2} \mathrm{O}_{3} / \mathrm{TiO}_{2}$ and accessory mineral saturation thermometry. Eur J Mineral 19: 859-870

Kelemen PB, Shimizu N, Dunn T (1993) Relative depletion of niobium in some arc magmas and the continental crust: partitioning of $\mathrm{K}, \mathrm{Nb}, \mathrm{La}$ and $\mathrm{Ce}$ during melt/rock reaction in the upper mantle. Earth Planet Sci Lett 120: 111-134

Kieffer B, Arndt N, Lapierre H, Bastien F, Bosch D, Pecher A, Yirgu G, Ayalew D, Weise D, Jerram DA, Keller F, Meugniot C (2004) Flood and shield basalts from Ethiopia: magmas from the African superswell. J Petrol 45: 793-834

King PL, White AJR, Chappell BW, Allen CM (1997) Characterization and origin of aluminous A-type granites from the Lachlan Fold belt, southeastern Australia. J Petrol 38: 371-391

Kovalenko DV, Chernov EE (2008) Paleomagnetism of Carboniferous-Permian and Early Jurassic geological complexes in Mongolia. Izv Phys Solid Earth 44: 427-441

Kovalenko VI, Yarmolyuk VV, Kovach VP, Kotov AB, Kozlovsky AM, SAL'NiKova EB, LaRIN AM (2004) Isotope provinces, mechanisms of generation and sources of the continental crust in the Central Asian Mobile Belt: geological and isotopic evidence. J Asian Earth Sci 23: 605-627

Kozlovsky AM, Yarmolyuk VV, Savatenkov VM, KoVACH VP (2006) Sources of basaltoid magmatism in rift settings at an active continental margin: example from bimodal association of the Noyon and Tost ranges in the Late Paleozoic Gobi-Tien Shan Rift Zone, southern Mongolia. Petrology 14: 337-360

Kozlovsky AM, Yarmolyuk VV, SAL'NiKova EB, Travin AV, Kotov AB, Plotkina JV, Kudryashova EA, SAVATENKov VM (2015) Late Paleozoic anorogenic magmatism of the Gobi Altai (SW Mongolia): tectonic position, geochronology and correlation with igneous activity of the Central Asian Orogenic Belt. J Asian Earth Sci 113: 524-541

KRETZ R (1983) Symbols for rock-forming minerals. Amer Miner 68: 277-279

Leake BE, Wooley AR, Arps CES, Birch WD, Gilbert MC, Grice JD, Hawthorne FC, Kato FC, Kisch HJ,
KrivovicheV VG, Linthout K, Laird J, Mandarino JA, Maresch WV, Nickel EH, Rock NMS, SchumACHER JC, SMith DC, StePHenson NCN, Ungaretti L, WhitTAKER EJW, GuO Y (1997) Nomenclature of amphiboles: report of the Subcommittee on Amphiboles of the International Mineralogical Association on New Minerals and Mineral Names. Canad Mineral 35: 219-246

Le Bas MJ, Le Maitre RW, Streckeisen A, Zanettin B (1986) A chemical classification of volcanic rocks based on the total alkali-silica diagram. J Petrol 27: 745-750

Li D, He DF, Santosh M, Tang JY (2014) Petrogenesis of Late Paleozoic volcanics from the Zhaheba Depression, East Junggar: insights into collisional event in an accretionary orogen of Central Asia. Lithos 187: 167-193

LitvinovsKy BA, Jahn BM, ZANVILEVICH AN, SAUNDERs A, Poulain S, KuZmin DV, Reichow MK, Titov AV (2002) Petrogenesis of syenite-granite suites from the Bryansky Complex (Transbaikalia, Russia): implications for the origin of A-type granitoid magmas. Chem Geol 189: 105-133

Liv Q, Zhao GC, Han YG, Eizenhöfer PR, Zhu YL, Hou WZ, ZHANG XR (2017) Timing of the final closure of the Paleo-Asian Ocean in the Alxa Terrane: constraints from geochronology and geochemistry of Late Carboniferous to Permian gabbros and diorites. Lithos 274-275: 19-30

LiU W, LIU XJ, LiU LJ (2013) Underplating generated A- and I-type granitoids of the East Junggar from the lower and the upper oceanic crust with mixing of mafic magma: insights from integrated zircon $\mathrm{U}-\mathrm{Pb}$ ages, petrography, geochemistry and $\mathrm{Nd}-\mathrm{Sr}-\mathrm{Hf}$ isotopes. Lithos 179: 293-319

Long X, Yuan C, Sun M, Xiao W, Zhao G, Wang Y, CAI K, XIA X, XIE L (2009) Detrital zircon ages and Hf isotopes of the Early Paleozoic flysch sequence in the Chinese Altai, NW China: new constrains on depositional age, provenance and tectonic evolution. Tectonophysics 480: 213-231

Mao QG, Xiao WJ, Fang TH, Windley BF, Sun M, Ao SJ, Zhang JE, Huang XK (2014) Geochronology, geochemistry and petrogenesis of Early Permian alkaline magmatism in the Eastern Tianshan: implications for tectonics of the Southern Altaids. Lithos 190-191:37-51

McCulloch MT, Gamble JA (1991) Geochemical and geodynamical constraints on subduction zone magmatism. Earth Planet Sci Lett 102: 358-374

McKenzie D, O'Nions R (1991) Partial melt distributions from inversion of rare earth element concentrations. J Petrol 32: 1021-1091

MERLET C (1994) An accurate computer correction program for quantitative electron probe microanalysis. Microchim Acta 114-115: 363-376

McDonough WF, Sun SS (1995) The composition of the Earth. Chem Geol 120: 223-253

Morimoto N (1998) Nomenclature of pyroxenes. Mineral Petrol 39: 55-76 
Nissen EN, Walker RT, Baysgalan A, Carter A, Fattahi M, Molor E, Schnabel C, West AJ, Xu S (2009) The late Quaternary slip-rate of the Har-Us-Nuur Fault (Mongolian Altai) from ${ }^{10} \mathrm{Be}$ and luminescence dating. Earth Planet Sci Lett 286: 467-478

Pearce JA (1996) Sources and settings of granitic rocks. Episodes 19: 120-125

Pearce JA (2008) Geochemical fingerprinting of oceanic basalts with applications to ophiolite classification and the search for Archean oceanic crust. Lithos 100: 14-48

Pearce JA, Cann JR (1973) Tectonic setting of basic volcanic rocks determined using trace element analyses. Earth Planet Sci Lett 19: 290-300

Pearce JA, Norry MJ (1979) Petrogenetic implications of $\mathrm{Ti}, \mathrm{Zr}, \mathrm{Y}$, and $\mathrm{Nb}$ variations in volcanic rocks. Contrib Mineral Petrol 69: 33-47

Peccerillo A, TAYlor SR (1976) Geochemistry of Eocene calc-alkaline volcanic rocks from the Kastamonu Area, Northern Turkey. Contrib Mineral Petrol 58: 63-81

Pillonen PC, Lalonde AE, McDonald AM, Gault RA, LARSEN AO (2003) Insights into the astrophyllite group I. Nomenclature, composition and development of a standardized general formula. Canad Mineral 41: 1-26

Ridolfi F, Renzulli A, Puerini M (2010) Stability and chemical equilibrium of amphibole in calc-alkaline magmas: an overview, new thermobarometric formulations and application to subduction related volcanoes. Contrib Mineral Petrol 160: 45-66

RUDNICK RL, GAO S (2004) Composition of the continental crust. In: Holland HD, TuREKian KK (eds) Treatise on Geochemistry Vol. 3, The Crust (RUDNICK RL ed). Elsevier-Pergamon, Oxford, pp 1-64

RUTTER MJ, WyLLIE PJ (1988) Melting of vapour absent tonalite at $10 \mathrm{kbar}$ to simulate dehydration melting in the deep crust. Nature 331: 159-160

Schmidt MW, Thompson AB (1996) Epidote in calcalkaline magmas: an experimental study of stability, phase relationships, and the role of epidote in magmatic evolution. Amer Miner 81: 462-474

Shen XM, Zhang HX, Wang Q, Wymanc DA, Yang YH, (2011) Late Devonian-Early Permian A-type granites in the southern Altay Range, Northwest China: petrogenesis and implications for tectonic setting of " $\mathrm{A}_{2}$-type" granites. J Asian Earth Sci 42: 986-1007

SOEJONo I, BuriáNeK D, JANOUŠEK V, SvoJTKA M, ČÁP P, ERBAN V, GANPUREV N (2017) A reworked Lake Zone margin: chronological and geochemical constraints from the Ordovician arc-related basement of the Hovd Zone (western Mongolia). Lithos 294-295: 112-132

SoEJono I, ČÁP P, Míková J, JANOušEK V, BuRiáNeK D, Schulmann K (2018) Early Palaeozoic sedimentary record and provenance of flysch sequences in the Hovd Zone (western Mongolia): implications for the geodynamic evolution of the Altai accretionary wedge system.
Gondwana Res 64:163-183

SteigER RH, JÄGER E (1977) Subcommission on Geochronology: convention on the use of decay constants in geoand cosmochronology. Earth Planet Sci Lett 36: 359-362

Sun SS, McDonough WF (1989) Chemical and isotopic systematics of oceanic basalts: implications for mantle composition and processes. In: SAUnders AD, Norry $M$ (eds) Magmatism in the Ocean Basins. Geological Society of London Special Publications 42: 313-345

Sun M, Yuan C, Xiao W, LONG Xia X, Zhao G, Lin S, Wu F, KRÖNER A (2008) Zircon U-Pb and Hf isotopic study of gneissic rocks from the Chinese Altai: progressive accretionary history in the early to middle Palaeozoic. Chem Geol 247: 352-383

Sylvester PJ (1989) Post-collisional alkaline granites. J Geol 97: 261-280

ȘenGör A, Natalin B, BurtMan V (1993) Evolution of the Altaid tectonic collage and Paleozoic crustal growth in Eurasia. Nature 364: 299-307

TAYLOR SR, McLenNan SM (1995) The geochemical evolution of the continental crust. Rev Geophys 33: 241-265

Tong Y, Wang T, Jahn B, Sun M, Hong DW, Gao JF (2014) Post-accretionary Permian granitoids in the Chinese Altai orogen: geochronology, petrogenesis and tectonic implications. Amer J Sci 314: 80-109

TURNER SP, FODEN JD, MORRISON RS (1992) Derivation of some A-type magmas by fractionation of basaltic magma: an example from the Padthaway Ridge, South Australia. Lithos 28: 151-179

VERNON RH (1991) Interpretation of microstructures of microgranitoid enclaves. In: DidIER J, BARBARIN B (eds) Enclaves and Granite Petrology. Developments in Petrology 13, Elsevier, Amsterdam, pp 277-291

Wang Q, Wyman DA, Zhao ZH, Xu JF, Zheng HB, XIONG XL, DAI DX, Li HC, ChU ZY (2007) Petrogenesis of Carboniferous adakites and $\mathrm{Nb}$-enriched arc basalts in the Alataw area, northern Tianshan Range (western China): implications for Phanerozoic crustal growth in the Central Asia Orogenic Belt. Chem Geol 236: 42-64

Wang ZG, Chen YL, Dong ZS, Wu MQ, Zhang J (1993) The high-alkaline intrusive rock belts in northern Xinjiang: their geology, geochemistry and genesis. In: Tu GZ (ed) Progress of Solid-Earth Sciences in Northern Xinjiang, China. Science Publishing House, Beijing, pp 163-172 (in Chinese)

WATSON EB, HARRISON TM (1983) Zircon saturation revisited: temperature and composition effects in a variety of crustal magma types. Earth Planet Sci Lett 64: 295-304

Whalen JB, Currie KL, Chappell BW (1987) A-type granites: geochemical characteristics, discrimination and petrogenesis. Contrib Mineral Petrol 95: 407-419

Winchester JA, Floyd PA (1977) Geochemical discrimination of different magma series and their differentiation products using immobile elements. Chem Geol 20: 325-343 
Wu FY, Sun DY, Li HM, JAHN BM, WiLdE SA(2002)A-type granites in northeastern China: age and geochemical constraints on their petrogenesis. Chem Geol 187: 143-173

Xiao WJ, Windley BF, Badarch G, Sun S, Li J, Qin K, WANG Z (2004) Palaeozoic accretionary and convergent tectonics of the southern Altaids: implications for the growth of Central Asia. J Geol Soc, London 161: 339-342

Yang W-B, Niu HC, Shan Q, Sun WD, Zhang H, Li NB, JIANG YH, YU XY (2014) Geochemistry of magmatic and hydrothermal zircon from the highly evolved Baerzhe alkaline granite: implications for $\mathrm{Zr}-\mathrm{REE}-\mathrm{Nb}$ mineralization. Miner Depos 49: 451-470

YARMOLYUK VV, KoVALENKO VI (1991) Rift Magmatism of Active Continental Margins and Its Ore Potential. Nauka, Moscow, pp 1-263 (in Russian)

Yarmolyuk VV, Kovalenko VI (2001) Late Riphean breakup between Siberia and Laurentia: evidence from intraplate magmatism. Dokl Earth Sci 379: 525-528

Yarmolyuk VV, Kovalenko VI, Kozlovsky AM, VoRontsov AA, Savatenkov VM (2005) Late PaleozoicEarly Mesozoic rift system of Central Asia: composition of magmatic rocks, sources, order of formation and geodynamics. In: Kovalenko VI (ed) Tectonic Problems of Central Asia. World of Science, Moscow, pp 197-226

Yarmolyuk VV, Kovalenko VI, Sal'nikova EB, Kovach VP, Kozlovsky AM, Kotov AB, LebedeV VI (2008) Geochronology of igneous rocks and formation of the Late Paleozoic south Mongolian active margin of the Siberian Continent. Stratigr Geol Correl 16: 162-181

Yarmolyuk VV, KuzMin MI, KozLovsky AM (2013a) Late Paleozoic-Early Mesozoic within-plate magmatism in north Asia: traps, rifts, giant batholiths, and the geodynamics of their origin. Petrology 21: 101-126

YarmolyuK VV, KuZMin MI, Vorontsov AA, Khomutova MY (2013b) West Pacific-type convergent boundaries: role in the crust growth history of the Central-Asian Orogeny. J Asian Earth Sci 62: 67-78

YARMOlYuk VV, Kozlovsky AM, KuzMin MI (2016) Zoned magmatic areas and anorogenic batholith formation in the Central Asian Orogenic Belt (by the example of the Late Paleozoic Khangai magmatic area). Russ Geol Geophys 57: 357-370

YuAN L, Zhang X, Xue F, Liu F (2016) Juvenile crustal recycling in an accretionary orogen: insights from contrasting Early Permian granites from central Inner Mongolia, North China. Lithos 264: 524-539
Zhang CL, Zou H, Yao CY, Dong YG (2014) Origin of gabbroic intrusions in the southern margin of the Altai Orogenic Belt: a possible link to the Permian Tarim mantle plume? Lithos 204: 112-124

Zhang X, Zhang H, Tang Y, Wilde SA, Hu Z (2008) Geochemistry of Permian bimodal volcanic rocks from central Inner Mongolia, North China: implication for tectonic setting and Phanerozoic continental growth in Central Asian Orogenic Belt. Chem Geol 249: 262-281

Zhang X, Wilde SA, Zhang H, Zhai M (2011) Early Permian high-K calc-alkaline volcanic rocks from NW Inner Mongolia, North China: geochemistry, origin and tectonic implications. J Geol Soc, London 168: 525-543

Zheng YF, Wu RX, Wu YB, Zhang SB, YuAN H, Wu FY (2008) Rift melting of juvenile arc-derived crust: geochemical evidence from Neoproterozoic volcanic and granitic rocks in the Jiangnan Orogen, South China. Precambr Res 163: 351-383

Zonenshain LP, KuZmin MI, Natapov LM (1990) Geology of the USSR: A Plate-Tectonic Synthesis. American Geophysical Union, Geodynamics Series Vol. 21. Washington, DC, pp 1-242

ŽÁčEK V, BuriáneK D, PéCSKaY Z, ŠKoda R (2016) Astrophyllite-alkali amphibole rhyolite, an evidence of Early Permian A-type alkaline volcanism in the western Mongolian Altai. J Geosci 61: 93-103

ŽÁČEK V, BohdáleK P, Břízová E, BuriáneK D, ČÁP P, Enkhjargal M, Franců J, GelegJamts A, Guy A, HanžL P, HaVlíčeK P, Henrion E, HoŠEK J, JELÉnEK J, KnÉSL I, Karenová J, Kociánová L, KotKová J, Krejčí Z, Mixa P, Mrlina J, Pecina V, Pécskay Z, Prudhomme A, Soejono I, SvojtKa M, ŠimůneK Z, ŠKoda R, Verner K, Vondrovic L, Vorel T, VránA S, Čopjaková R (2017a) Mongol Altai 50 - a Development Cooperation Project of Czech Republic with Mongolia in geology (2013-2016). Geosci Res Reports 50: 159-166

ŽáČEK V, BuriáneK D, ČÁP P SOeJONo I, Vorel T, HavlíčEK P (2017b) New geological maps $1: 50,000$ of the Mongolian Altai. In: ŠIMON L, Kováčová M, Ozdínová S, Michalík J, Pivko D, Goliáš V, Bokr P, Tomanová Petrová P, Gilíková H (eds) Otvorený geologický kongres Slovenskej geologickej spoločnosti a České geologické společnosti, Vysoké Tatry, 14-17 June, 2017. Zborník abstraktov a exkurzný sprievodca. Slovenská geologická spoločnost, Bratislava, pp 79 